NBER WORKING PAPER SERIES

\title{
LENDING BOOMS, RESERVES AND THE SUSTAINABILITY OF SHORT-TERM DEBT: INFERENCES FROM THE PRICING OF SYNDICATED BANK LOANS
}

\author{
Barry Eichengreen \\ Ashoka Mody \\ Working Paper 7113 \\ http://www.nber.org/papers/w7113
NATIONAL BUREAU OF ECONOMIC RESEARCH 1050 Massachusetts Avenue
Cambridge, MA 02138
May 1999

This paper was prepared for the Interamerican Seminar on Macroeconomics, Rio de Janeiro, 3-5 December 1998; we thank the participants and especially our discussants, Sebastian Edwards and Aaron Tornell. For research assistance above and beyond the call of duty we are indebted to Qiming Chen. Ken Wood, Freyan Panthaki, and other members of the Emerging Markets Division of the Research Department of the International Monetary Fund were instrumental in helping to construct the data set. Finally, we thank the World Bank's Research Committee and the Ford Foundation (through the UC Berkeley Project on International Financial Architecture) for partially financing the research for this paper. The views expressed herein are those of the authors and do not necessarily reflect the views of the National Bureau of Economic Research.

(c) 1999 by Barry Eichengreen and Ashoka Mody. All rights reserved. Short sections of text, not to exceed two paragraphs, may be quoted without explicit permission provided that full credit, including ${ }^{\circ}$ notice, is given to the source. 
Lending Booms, Reserves and the Sustainability

of Short-Term Debt: Inferences from the

Pricing of Syndicated Bank Loans

Barry Eichengreen and Ashoka Mody

NBER Working Paper No. 7113

May 1999

JEL No. F3

\section{ABSTRACT}

This paper analyzes the determinants of spreads on syndicated bank lending to emerging markets, treating the loan-extension and pricing decisions as jointly determined. Compared to the bond market, our findings highlight the role of international banks in providing credit to smaller borrowers about whom information is least complete and, more generally, support the interpretation of bank finance as dominating that segment of international financial markets characterized by the most pronounced information asymmetries. Domestic lending booms and low reserves in relation to short-term debt have been priced in the expected manner by international banks. The high level of short-term debt in East Asia was supported by high growth rates but was characterized by a knifeedge quality.

Barry Eichengreen

Department of Economics

University of California

Berkeley CA 94720-3880

and NBER

Eichengr@econ.berkeley.edu
Ashoka Mody

Development Prospects Group

The World Bank

Washington, D.C. 20433

amody@worldbank.org 


\section{Introduction}

Syndicated bank lending is the Chevy Cavalier of international financial markets. For the same reasons that Motor Trend devotes little space to basic transportation, academics pay little attention to international bank lending, preferring to concentrate on rapidly growing market segments like the sport-utility vehicle and the international bond market, or exotic products like high-performance sports cars and derivative credit instruments. What is relevant to the vast majority of consumers thus receives relatively little attention.

In this paper we argue that more attention to international bank lending is warranted for three reasons. First, the syndicated bank loan remains one of the workhorses of international capital markets. As Table 1 shows, loan commitments have been every bit as important as bonds in the first half of the 1990s. While new bond issues rose from negligible levels at the beginning of the 1990s to more than $\$ 100$ billion in calendar year 1996 and \$128 billion in 1997 before falling back in the wake of the Asian crisis, loan commitments have also trended steadily upward, actually exceeding bond issues in every year through 1995 but one (1993) and nipping at the heels of new bond issues in both 1996 and 1997.

Second, international bank lending is particularly important for the private-sector borrowers whose participation is the distinctive feature of international capital markets in the 1990s and who are likely to dominate the market to an even greater extent in the future as the privatization of state enterprise and the liberalization of capital markets proceed. Already one of the striking contrasts between bond and bank lending is the extent to which sovereigns and other governmental borrowers continue to rely on the bond market, while private borrowers are disproportionately important to the market in international bank loans. This is what we should expect, of course, to the extent that 
private-sector borrowers about whom information is least complete establish long-term relationships with banks as a way of resolving information problems. But it means that the emerging-market bond spreads on which most recent analysis focuses are likely to provide little, and for that matter potentially misleading, information about what is going on in this market segment (as Figure 1 suggests). ${ }^{1}$

A third reason for focussing on loans is the controversy that has swirled around the behavior of international bank lending in the wake of the Asian crisis. Spreads on syndicated bank loans show relatively little variation compared to spreads on international bonds, raising questions about whether bank lenders are properly pricing country and credit risk. Low interest rates in Tokyo are said to have encouraged Japanese banks to develop an excessive appetite for emerging-market debt. Growing competition in Europe as a result of the Single Market is said to have eroded domestic margins and to have encouraged second-tier European banks to scramble into Asian markets in search of yield. ${ }^{2}$ Moreover, with banks enjoying deposit insurance, lender-of-last-resort services, and in some cases implicit and explicit guarantees-along with the expectation that they will be able to withdraw their funds on demand insofar as the IMF injects offsetting resources in response to a crisis—it has been suggested that spread compression on

${ }^{1}$ Figure 1 plots average spreads on all new loan commitments and new bond issues in the 1990s. In only half the quarters do average spreads on loans and bonds move in the same direction. Note that average loan spreads are much smaller than those for bonds and move in a smaller band. A clue to the reason lies in the contrasting reactions to the Mexican and Asian crisis. Following the devaluation of the Mexican peso in December 1994, bond and bank loan spreads in the primary market diverge. The decline in bond market spreads reflects a sharp change in the composition of the pool of borrowers: only the best quality issuers were able to tap the bond markets, leaving high-risk borrowers, from Latin America in particular, effectively rationed out of the market. In comparison, the commercial loan market, dominated by Asian borrowers, was less affected. By contrast, following the onset of the Asian crisis in the last quarter of 1997, new bank loan commitments fell sharply and spreads increased (to their highest quarterly level since the start of the time period under consideration). The response of primary bond market spreads was muted by comparison.

2 Indeed, one of the striking features of bank lending to emerging markets, as we shall see, is the extent to which it is dominated by Asian borrowers. 
syndicated bank loans to developing countries is an indication of the extent of moral hazard.

All these are reasons why bank lending to emerging markets is deserving of study. Yet, to our knowledge, there exists no systematic study of the determinants of the pricing of international bank loans in the 1990s that can be used to shed light on these issues. This paper takes a first step in that direction. It analyzes the pricing of over 4500 international loan commitments to developing countries between 1991 and 1997, years which span the recent period of heavy lending to emerging markets. This is, in principle, the entire population of bank loans to emerging markets. We pay special attention to problems of sample selection, since there are good reasons to suspect that borrowers that rely on loan commitments for external finance differ in important respects from other debtors. We analyze both the borrowing decision of enterprises and governments and the pricing decisions of their bank underwriters, addressing problems of selectivity bias by treating the two decisions jointly.

Section II reviews the theoretical literature on bank lending to emerging markets with the goal of identifying what is special about bank loan commitments as opposed to other forms of international borrowing and lending. Section III introduces our data set and describes its features. (More details appear in Appendix A.). Subsequent sections then consider the roles of short-term debt and domestic bank credit (Section IV), the determinants of access to international bank loans (Section V), and the implications of analyzing the commitment and pricing decisions jointly, with a focus on differences in pricing across regions and over time (Section VI). The bond market providing the obvious benchmark for assessing our results, we summarize our parallel analysis of the 
bond issuance decision and launch spreads on emerging market bonds (Eichengreen and Mody 1998a,b) in Appendix B.

\section{Thinking About Loan Commitments}

While international bank lending is no new phenomenon, in the century preceding World War II the role of banks was limited to underwriting bond issues and to extending trade credits and making interbank deposits. This changed in the 1970s with the rise of intermediate term, floating rate, general obligation syndicated bank loans to developing countries. Syndicated bank lending exploded from less than $\$ 50$ billion in 1972 to more than $\$ 300$ billion in 1982, when it was interrupted by Mexico's debt moratorium. Net capital flows then reversed direction. Only at the end of the 1980s, with the completion of the major Brady Plan reschedulings, did the volume of bank lending to developing countries recover significantly in tandem with the growth of the bond market.

The rise of syndicated bank lending is typically understood in terms of three factors: information asymmetries, contract enforcement, and moral hazard. In turn, changes in these factors are invoked to explain the growth of the bond market in the 1990s.

\section{Information Asymmetries}

Bond and equity issues have the advantage of speed and low transactions costs. An infrastructure project needs only to be given a credit rating by a rating agency, at which point it can be brought to the market. A syndicated bank loan, in contrast, must go through a lengthy process of approval by a series of internal loan committees. It is thus striking that relatively few infrastructure projects in emerging markets have secured financing through securities markets. Bank loans must have other advantages. 
An obvious explanation is that banks have sunk the costs of investing in a technology for monitoring borrowers. The same theories of delegated monitoring that emphasize the informational role of banks vis-à-vis smaller, less reputable domestic borrowers similarly suggest a role for banks in providing external finance for precisely those foreign borrowers about whom market information is least complete. These "pecking order theories" of finance suggest that emerging market borrowers seeking external finance graduate from bank finance to bond finance and finally to equity finance as information about their credit worthiness becomes more complete.

One of the earliest formalizations of this notion, by Kletzer (1984), emphasized asymmetric information about the level of the debtor's external obligations. Kletzer pointed out that it can be important for creditors to know the aggregate amount loaned to a debtor (since that debtor may otherwise borrow in excess of its credit ceiling, at which point it will have an incentive to renege on its commitments) and similarly to know the terms of earlier loans. The role of the bank syndicate is to provide a mechanism through which lenders can pool information. Kletzer shows that when creditors can only observe their own loans they will lend larger amounts at higher interest rates than when there is common information. Under relatively general conditions the borrower is better off with observability, since the reduction in interest rates more than compensates it for the reduction in credit availability. Hence, where information is least complete, bank loan contracts will be incentive compatible.

This formulation is difficult to reconcile with the fact that developing countries often appear to be able to borrow more freely from banks than bond markets (Allen 1990). This suggests that the emphasis should be placed not on the difficulty of verifying the level of indebtedness per se, but rather on the difficulty of obtaining and evaluating 
information about other borrower characteristics affecting the willingness and ability to repay. While it may be difficult for bondholders to evaluate the likely construction costs and prospective revenue stream associated with an infrastructure or manufacturing project, commercial and investment banks have the project-evaluation capability and the long-term relationship with the borrower needed to obtain the relevant information and carry out this evaluation.

Note that these theories of delegated monitoring, while they can explain the preference for bank over bond finance, cannot by themselves explain the preference for syndicated bank lending. To this one must add another consideration, like the assumption that individual emerging market loans are too large for individual banks to finance given capital requirements, restrictions on loan concentrations, and prudent riskmanagement practices. Thus, syndicated bank lending provides both delegated monitoring and portfolio diversification services. The fact that even direct syndicates (in which there is no lead bank) usually appoint a manager or agent to act as the conduit for information between the syndicate and borrower is consistent with this interpretation.

It is then straightforward to explain the recent rise of the bond market in terms of improvements in the information environment. Emerging markets having strengthened auditing, accounting and disclosure requirements for their banks and corporates, the informational advantages of the banks eroded. But as the Asian crisis serves to remind, there remains a significant gap in auditing, accounting and disclosure standards between emerging and advanced-industrial countries. It is not surprising that there remains a significant role for the banks. 


\section{Contracting and Recontracting}

Because the banks comprising a syndicate form a cohesive group (relative to bondholders who tend to be more numerous and heterogeneous), banks should be better positioned to enforce debt contracts (Edwards, 1986). If concerted lending is required to maximize the value of existing claims, a bank syndicate will be in a better position to undertake it than a large number of disbursed bondholders. Sachs and Cohen (1982) were among the first to argue that the cohesiveness of bank syndicates opens up opportunities for renegotiating defaulted debts. In their model, spreads on bank loans are lower than spreads on bonds, other things equal, since in the event of debt-servicing difficulties bank loans can be rescheduled, while in the case of bonds there is only the option of default. The fact that the syndicated loan sector generally allows borrowers to raise larger sums than they would be able to obtain through the bond market is consistent with this view. So is evidence provided by Preece and Mullineaux (1996), who show that the response on capital markets to announcements of private financings declines with the number of lenders in the syndicate, as if rising numbers imply rising recontracting costs, consistent with the assumption that a role of bank syndicates is to lend where renegotiation is likely to be important.

Eaton and Gersovitz (1981) invert the argument, pointing out that default can be devastating for the borrower as well as the lender, so that the possibility of rescheduling bank loans encourages borrowers to engage in brinkmanship, which renders bank loans riskier than bonds. Bonds may be preferred to bank loans, in other words, because the absence of sharing, majority voting and collective representation clauses heightens the cost of default and therefore provides a precommitment technology. 
The obvious reconciliation is that both ex ante bonding and ex post recontracting have value. Debtors who value bonding will go through the bond market (the repetition in this sentence is purposeful), while debtors who place a high shadow price on the ability to recontract will borrow from banks.

\section{Moral Hazard}

Finally, there is the possibility that lending to emerging markets is undertaken by banks because they are sheltered from the associated risks by the financial safety net. Among the first to emphasize moral hazard in international lending were Folkerts-Landau (1985) and Gutentag and Herring (1985), who argued that the risk premia charged on international bank loans were likely to be smaller than those on international bonds insofar as central banks and governments provide implicit or explicit insurance against the risks of international bank lending. This explanation has received considerable attention in the wake of the Asian crisis, academics and officials having argued that banks were inclined to lend (and debtors to borrow) because they enjoyed implicit and/or explicit guarantees.

\section{Data}

To shed further light on these interpretations, we consider the pricing of syndicated bank loans to emerging markets in the 1990s. We limit our attention to loans priced off the London interbank offer rate (LIBOR). Thus, the interest paid by the borrower is LIBOR plus a spread, which reflects the risk premium. Over the life of the loan, the spread stays fixed but the interest rate paid moves with LIBOR. Between 1991 and 1997, just over 5000 LIBOR-based loans were made to emerging markets. We are able to analyze the spreads on about 4500 loans, the subset of the population for which complete loan and country characteristics are available. 


\section{The Loans: Numbers, Spreads, and Issuers}

East Asian borrowers have dominated the international loan market. Of the 5,115 loans issued between 1991 and 1997, 3,373 were to East Asia, followed by Latin America and the Caribbean with 543, and Eastern Europe, Middle East and North Africa, and South Asia each with about 350 loans. $^{3}$

Table 2 shows that international loans have been made largely to private borrowers (especially in manufacturing and finance). Public sector borrowers (as distinct from sovereigns) have also borrowed in significant numbers, especially for infrastructure and other services (the category "Government" in Table 2 refers to borrowings supported by local or national governments without an identified sectoral use of proceeds).

The average spread above LIBOR is 112 basis points. For emerging market bonds issued during the same period, spreads were significantly larger, averaging 256 basis points (Table 3 ). The average spread on loans remained relatively steady, ranging from a low of 98 basis points in 1991 to a high of 117 basis points in 1994. Thus, bond spreads are larger on average and more variable. Interestingly, the ratio of bond to loan spreads declined over the period, from more than three between 1991 and 1993 to about two between 1994 and 1997, perhaps indicating some maturing of the bond market. The higher bond spreads do not simply reflect the regional composition of loans and bonds: in fact, loan spreads are lower than bond spreads within each individual region. Loans also have significantly shorter maturities than bonds (3-4 years verses 8-10 years on average).

Private borrowers typically pay higher spreads than public borrowers (Table 4), and spreads are lower for loans contracted by financial institutions. Except where contracted directly by sovereigns, loans for infrastructure and utilities command higher spreads than

\footnotetext{
${ }^{3}$ East Asia has also been the most prominent floating-rate bond market issuer, although Latin America has
} 
loans for investment in other sectors, a somewhat surprising finding in view of the generally assumed stability of earnings in this sector. (The longer tenor of the loans in this sector (Table 5) may partly explain the higher spreads, as we show below.)

\section{Explanatory Variables}

We used a variety of macroeconomic and financial indicators to study the loan commitment and pricing decisions. Throughout, our goal was to keep the empirical specification as comparable as possible to that used in our previous work on international bonds. Thus, we regressed the loan spread (including fees) on standard macroeconomic characteristics of the country of the borrower using data assembled principally from the World Bank's World Debt Tables and Global Development Finance and the IMF's World Economic Outlook data base and International Financial Statistics, although where necessary we used national sources to supplement these data. As in our previous work, we included the ratio of debt to GNP, whether the country had rescheduled in the preceding year, the ratio of debt service to exports (the lagged rate of GDP growth in 1990 prices, denominated in domestic currency), and the variance of export growth. To proxy for other more-difficult-to-quantify characteristics of country credit worthiness we included the residual from a first stage regression of the most recent sovereign credit rating (gathered from Institutional Investor Magazine and published each March and September) on a vector of standard economic and financial determinants. ${ }^{4}$ We also considered the share of short term debt in total commercial bank debt (provided by the

a significant presence in the fixed-rate bond market.

4 We included only the residual component of the credit rating since the raw credit rating is highly correlated with a number of the other economic and financial indicators in the equation; indeed, it is well known that the rating agencies rely on those indicators when doing the rating exercise. In identifying explanatory variables for the first-stage regression we followed the literature on the standard determinants of sovereign credit ratings (e.g. Cantor and Packer 1996 and Haque et al. 1996). 
Bank of International Settlements) and the ratio of domestic credit to GDP, two variables that turn out to be important in what follows.

As characteristics of the issuer we considered whether it was a private entity, whether it was a supranational, and whether it had borrowed previously on the syndicated loan market. As a measure of global credit conditions we included the log of the 3-year U.S. treasury rate (the average maturity for loans being between 3 and 4 years). As characteristics of the loan we included its amount, maturity, and currency of denomination. Finally, we included the industrial classification of the borrower (manufacturing, financial services, infrastructure and other utilities, other services, and government).

\section{Basic Results}

We use ordinary least squares regressions to highlight some of the basic relationships in the data. The first column in Table 6 shows that loan spreads decline with the amount loaned (reflecting economies of scale) and rise with loan maturity (reflecting greater risk as maturity increases and suggesting that lenders value the liquidity of short-term loans and their ability to discipline borrowers). Private loans and Latin American borrowers pay higher spreads.

The second column introduces a variable designed to capture the importance of relationship banking. The first time a borrower appears during the 1991 to 1997 time frame, the variable takes the value 1; it is then incremented each time the borrower reappears. Repeated borrowings (the number of times the borrower has come to the bank loan market previously) have a very strong negative effect consistent with the notion that 
relationship banking is used to overcome information asymmetries. ${ }^{5}$ Though many borrowers came to the market only once during this period (of the 5115 borrowings, 2173 were from one-time borrowers), several borrowed on multiple occasions. ${ }^{6}$ The point estimate in the second column of Table 6 suggests that an additional loan commitment reduces the spread by 2.4 percent, other things equal. Note that the coefficient on the "private" dummy becomes less significant when the relationship variable is introduced, reflecting the higher incidence of multiple borrowing by private borrowers. ${ }^{7}$

Table 6 also indicates that borrowings in yen, and to a lesser extent deutsche marks, carry lower spreads, other things equal. This is consistent with the presumption that supply-side conditions (low Japanese funding costs, declining margins in Europe) helped to fuel lending to emerging markets. ${ }^{8}$ Financial institutions also pay lower spreads on their borrowings, consistent with the emphasis some observers have placed on the influence of implicit and explicit guarantees. When sectoral dummies are added, the significance of the maturity variable declines since, as noted, maturities vary between sectors. Note that the longer maturity of lending for infrastructure projects can help explain the unusually high spreads on such loans (referred to above), although spreads on loans for infrastructure (the omitted sectoral control) still remain unusually high.

5 This interpretation should be held cautiously, for a number of reasons. For one, we have only been able to construct a variable for repeated bank borrowings, not repeated borrowings from a syndicate headed by the same loan arranger. And second, there is the possibility that those who are repeatedly able to borrow from the banks differ in other ways that are not readily observed by the econometrician but are well known to all participants in financial markets, and not just to bank lenders.

${ }^{6}$ Over a thousand borrowings represented between the fourth and $10^{\text {th }}$ borrowings and about 500 were for borrowers who were entering into a loan contract on more than the tenth occasion.

7 However, the significance on the private dummy reappears when country characteristics are introduced.

${ }^{8}$ We were also able to identify for about 3500 borrowers the nationality of the lead loan arranger. These results are not presented at this time because many observations are lost. However, the results for a subset of loans do tend to show, contrary to suggestions, that the existence of cross-default clauses and proportional sharing rules have rendered bank loans to LDCs homogeneous-in other words, that the value and pricing of a loan is not affected by the identity of the lender - that there is strong evidence here that the identity of the arranger affects the level of the spread. Consistent with the low cost of funds in 
In Table 7, we introduce a number of country characteristics to further explain the spreads charged. The majority of these carry over from our earlier analysis of bond spreads (Eichengreen and Mody 1998 a,b). The three debt variables (the debt/GNP ratio, a dummy for debt rescheduling if one occurred in the previous year, and the debt service/export ratio) show that, as for bonds, spreads rise with debt levels, a history of rescheduling, and higher debt service in relation to exports. High country growth rates enhance the ability to repay and reduce spreads; highly variable export growth, on the other hand, raises the risk of non-payment and increases the spread. The credit rating residual, which measures the effect of country credit rating factors not explicitly included in our analysis, always gives a strong negative sign: a larger residual implies a better rating and a lower spread. The directional influence of these variables is robust across subsamples (as discussed below), although their relative importance and statistical significance varies. $^{9}$

To get closer to some hypotheses that have featured in the recent debate over Asian crisis, we added measures of the country's short-term indebtedness and the ratio of domestic bank credit to GDP. Some observers have argued that, prior to the crisis, neither bank lenders nor other markets participants appreciated the risks associated with short-term debt. Our findings cast some doubt on this assumption: for the full set of loans, a low ratio of international reserves to short-term debt significantly raises spreads, while a larger share of short-term debt in country's total outstanding bank debt has a strong, significant, positive impact on spreads. This is a robust result that holds across regions, with the noteworthy exception of East Asia in recent years (as we discuss

Japan and the urgency of Japanese banks' search for yield, spreads on loans originated by Japanese banks consistently display the smallest spreads. 
below). Overall, however, banks appear to have attached a higher risk premium to borrowers in countries with large amounts of short-term debt even before the factor was highlighted in the recent crisis. ${ }^{10}$

A high ratio of domestic bank credit to GNP is a proxy for the existence of deep domestic financial markets. Other things equal, the presence of deep markets should reduce spreads on international bank borrowing by implying a more stable financial environment and more local competition for foreign lenders (Levine and Zervos 1998). While our findings confirm this presumption, the effect is small and statistically insignificant (see Column 3 of Table 7). To further examine the relationship between international bank spreads and domestic bank credit, we therefore added to the regression the interaction of the growth rate with the bank credit stock/GDP ratio (and its square). It appears that where rapid growth and high levels of bank credit are both present, spreads are higher (Columns 4 and 5). An interpretation is that high GNP growth rates fueled by the expansion of domestic credit (domestic credit booms) were viewed by the market with concern. Note that with the addition of the non-linear terms, the bank credit stock/GDP ratio now has a negative and significant sign while the squared term is positive and significant. In other words, at low levels of financial development and low growth rates, policy measures to improve financial intermediation bring value and reduce the costs of external borrowing, but when they spill over into unsustainable credit booms, they are regarded by the markets with alarm and worsen the terms of access to external funds.

9 Relative to Edwards (1986), we find the same signs on the coefficients for loan size, loan maturity, GDP growth, debt/GDP ratio, and the debt-service-to-export ratio but generally stronger and more robust effects.

${ }^{10}$ The coefficient on the interaction of short-term debt with the "relationship" variable shows that high short-term debt lowers the value of familiarity to the market. High growth reduces the risk premium associated with high-short term debt, although here too regional variations are important. 
Comparing these findings with our earlier results for the bond market

(reproduced in the Appendix B), one is struck by the similarity of the determinants of spreads. The debt variables, the growth of GDP, and the variance of export growth all enter with the same signs and significance in equations for the full set of bank loans and bonds. At the same time, some of the differences between the two data sets are consistent with the notion that borrowers and lenders resort to bank intermediation to attenuate information problems. The coefficient for private borrowers is smaller in the bank-loan equations, as if banks are better able to overcome the special information obstacles to lending to private entities. The effect of the country credit rating residual is smaller for bonds than bank loans, as if characteristics that are readily observable by the credit-rating agencies play a smaller role in this market.

\section{Determinants of Loan Commitments}

Since the (unobserved) characteristics of those who borrow from international banks are likely to be different from those that do not, we also estimate the spreads equation after correcting for selectivity bias. The procedure requires estimating a probit equation which distinguishes borrowers from non-borrowers. To estimate the probit, we created a set of observations for which the dependent variable took the value "zero" when a loan commitment did not materialize. If no loan was made to a specific type of issuer (private, public, or sovereign) in a particular country in a particular quarter, then a zero was recorded; where a loan commitment was made, we recorded a one. 
Results are reported in Table $8 .{ }^{11}$ We see that a rise in the U.S. treasury rate significantly increases the probability of observing a new loan commitment. This is very different from the finding for the bond market, where the treasury rate (for 10-year maturity, in keeping with the tenor of bonds issued) showed a strong negative sign. In Eichengreen and Mody (1998b), we noted that the primary effect of a rise in U.S. interest rates was through a decline in the issuance of bonds. Some have interpreted this phenomenon as a flight to quality: high interest rates lead bondholders to shun risky investments; in addition, risky borrowers may prefer to wait for better market conditions. For bank loans, in contrast, borrowers appear to be willing to pay higher rates in order to retain access to the market, which is plausible insofar as these are floating rate instruments (so that borrowing in periods of tight global credit conditions does not lock them into high interest rate).

The regional variation here is of some importance. For the East Asian subsample, the coefficient on the U.S. treasury rate, though positive, is not statistically different from zero; and, in some specifications, a higher interest rate lowers the probability of a bank loan commitment in East Asia, as in our analysis of the bond market, though the effect is rarely significant. An interpretation is that East Asian borrowers had relatively favorable access to the market (prior to the recent crisis) and were better able to wait for global credit conditions to improve. The East Asian coefficient contrasts with that for Latin America and South Asia, where higher interest rates increase the probability of new loan commitments. Our spreads equation with the correction for selectivity confirms that there is little significant impact of U.S. Treasury

\footnotetext{
${ }^{11}$ The reported coefficients for the probit are normalized to the partial derivative of the probability distribution function with respect to a small change in the independent variable evaluated at average values of the independent variable to facilitate interpretation.
} 
rates on spreads, in contrast to the selectivity corrected results for the bond market. The credit rating residual, the debt-to-GDP ratio, and the absence of recent debt rescheduling appear to act as screening variables in all regions, with favorable values increasing the probability of a loan. ${ }^{12}$ In regions other than East Asia, a higher debt-to-export ratio is associated with a higher probability of borrowing. Strikingly, higher domestic bank credit appears to be more strongly associated with foreign borrowing in East Asia than in other regions. As discussed in IMF (1998), this may reflect the extensive reliance of East Asian domestic financial systems on international credit, ironically for economies with such high savings rates.

In light of the recent attention paid to the level of international reserves (Feldstein, 1999), we examine their role from two perspectives. The ratio of reserves to short-term debt relates the adequacy of reserves to short-term obligations on capital account, while the ratio of reserves to imports measures reserve adequacy for trade-related obligations. ${ }^{13}$ The two reserve ratios turn out to be important in different ways. The lower is the level of reserves in relation to imports, the more limited is access to international loans, as if countries in more fragile payment positions find it more difficult to borrow. While this is a significant effect in the full sample and for each region, the differences across regions are noteworthy. Low reserves reduce access most dramatically in the relatively closed economies of South Asia and least in highly export-oriented East Asia. But when reserves are viewed in relation to short-term external debts, the opposite seems to be true.

\footnotetext{
${ }^{12}$ The exception is a recent debt rescheduling in Eastern Europe, which appears to be associated with a higher rather than a lower probability of observing subsequent loan commitments. South Asia did not reschedule debt in the period analyzed.

${ }^{13}$ As Fischer (1999) notes, "countries need to set their reserve holdings on the basis of capital, as well as current, account variables."
} 
More short-term debt does not screen out borrowers; rather, borrowers in countries with relatively low reserves relative to short-term debt are more likely to borrow again. ${ }^{14}$

Overall, then, the results for bank borrowing are similar to those for the bond market. The greater tendency for a heavy debt burden to ration borrowers out of the market in Latin America than East Asia is the same as we previously obtained using an entirely different data set for the bond market. Similarly, the ratio of debt service to exports strongly increases the probability of observing new loan commitments and new bond issues for Latin America but has a more modest effect in East Asia.

\section{Results with Selectivity Correction: Differences Across Regions and Over Time}

Following Heckman (1979), we assume that the error terms in the two equations are bivariate normal with standard deviations $\mathrm{s}_{1}$ and $\mathrm{s}_{2}$ and covariance $\mathrm{s}_{12}{ }^{2}$ (where $\mathrm{p}_{2}=$ $\left.\mathrm{s}_{12}{ }^{2} / \mathrm{s}_{1} \mathrm{~s}_{2}\right)$. The model can then be identified by the nonlinearity of the fitted probability in the selection equation and by the inclusion of independent variables in the selection equation that are not also included in the pricing equation. We estimated the system using maximum likelihood. Table 9 reports the same pricing equation as before, this time with the selectivity correction. The coefficients are reasonably robust to the selectivity correction. And by the standards of the bond market, syndicated bank lending exhibits little interregional instability. ${ }^{15}$

\footnotetext{
${ }^{14}$ Fischer (1999) points out that the demand for reserves will increase as capital accounts become more open. Our finding cautions that some part of the build-up in reserves may be unstable if it occurs through increases in private external short-term obligations.

${ }^{15}$ It will be noted, though, that the coefficients for Latin America are estimated imprecisely and that some of the South Asian coefficients are counterintuitive (e.g., that on the growth rate). Multicollinearity appears to be responsible for these problems. In the next section, we show that a pared down specification produces plausible results.
} 
The t-statistic of the coefficient on lambda, the Inverse Mills Ratio, summarizes the importance of selectivity. An insignificant lambda implies that the error terms in the probit and spreads equations are not correlated and that there is little selection bias. This appears to be the case when the full loan set is considered: lambda is small and statistically insignificant (the correlation between the error terms in two equations is negative 0.06). However, evidence of selectivity is stronger when we disaggregate regions. While the East Asian lambda is negative, that for the other regions is positive (which explains the absence of an effect in the full sample). The normal presumption would be a positive coefficient: entities with characteristics that make them unlikely borrowers but who come to the market anyway will be charged higher spreads. This is what we find for Latin American, Eastern Europe and South Asia. In East Asia, however, borrowers who are not expected to come to the market but do so anyway are paradoxically charged unusually low spreads. ${ }^{16}$

The bottom panel of Table 9 shows the point estimates at the regional mean values for GDP growth, short-term debt ratio, and the bank credit stock, all of which are entered interactively. For the full set of loans, we find the same signs on these variables as when there are no interaction terms: faster GDP growth and a higher bank credit stock reduce spreads, other things equal, while a higher ratio of short-term debt raises spreads. These results have plausible explanations, as discussed earlier. For East Asia, the high GDP growth rate has a double pay-off: not only does it have the direct effect of reducing spreads, but it mitigates the effect of short-term debt. Thus, while East Asia has the highest ratio of short-term debt of all regions (0.65 compared to 0.55 in Latin America

\footnotetext{
${ }^{16}$ This may reflect hard-to-measure characteristics of these countries associated with unusually favorable growth prospects ("Asian values"), implicit guarantees, or some other factor. Note, however, that the statistical significance of this coefficient is marginal.
} 
and 0.43 in Eastern Europe), the impact on spreads is (on the margin) smaller in Latin America or Eastern Europe. However, the high domestic-bank-credit-to-GDP ratio (2.9 compared to 1.1 in Latin America and 0.7 in Eastern Europe) coupled with high growth carries a penalty in terms of raising spreads. ${ }^{17}$

Considering the probit and spreads equations together allows us to interpret the impact of variables entering both equations in terms of supply and demand. Henceforth we use "demand" to refer to the demand by commercial banks for emerging market exposure and the term "supply," in keeping with our bond market terminology ("supply of bonds"), to refer to the willingness by emerging market borrowers to contract for international loans. The credit rating residual, the debt/GDP ratio and the debt rescheduling variable all affect the demand by commercial banks for exposure to emerging markets. Better credit—a larger credit rating residual, a smaller debt/GDP ratio, and absence of recent debt rescheduling — increases the probability of observing a new loan commitment while lowering the spread. This result parallels that for bonds.

For the full set of loans, the U.S. treasury rate appears to shift the demand curve-a rise in U.S. interest rates increases the probability of loans while lowering the spreads, suggesting that when interest rates rise banks are willing to lend more at lower spreads. ${ }^{18}$ However, regional differences are significant. For East Asia, the supply effect seems to predominate in the market for loans (as in the market for bonds): while a rise in the U.S. treasury rate narrows spreads, the change in the number of new loans is statistically insignificant, suggesting that the East Asians are able to move along a

\footnotetext{
${ }^{17}$ The signs for Latin America and Eastern Europe are the same as for the full set of loans. The withinSouth-Asia results are harder to interpret: the signs on all three variables are the opposite of those for the full loan set.

${ }^{18}$ Note, of course, that though the spreads decline, the overall interest rate charged to emerging markets borrower rises.
} 
relatively inelastic commercial bank demand curve. For Latin America the supply shift dominates as well, although it works in the opposite direction. With a rise in interest rates, the Latin American supply curve shifts out, increasing the number of loans while also requiring borrowers to pay higher spreads. The result for Latin American loans is thus in contrast to that for bonds, where a rise in interest rates was associated with lower issuance and higher spreads, indicating a fall in demand. The results suggest that, in periods of high interest rates, high quality borrowers (traditionally from East Asia and non-emerging-market countries) withdraw from the syndicated bank loan market temporarily, but Latin American issuers seek to retain access, for which they are willing to pay a higher price.

Another variable that mainly shifts the supply curve (as for bonds) is the ratio of debt service to exports: a higher ratio typically raises the number of new loans while increasing spreads. A variable that was not included in our earlier bond analysis, the ratio of reserves to short-term debt, also serves to shift supply: when reserves fall in relation to short-term debt, the number of new loans increases along with spreads. For East Asia, the increases in stock of domestic bank credit in relationship to GDP are associated with shifts in supply for international loans.

Finally, we consider changes over time in an attempt to see if the data throws some light on recent events. We estimate the same model as in Table 9 for East Asian loan commitments for different time periods. For each of these periods, we then calculate the marginal effect of the variables of interest. (Table 10). ${ }^{19}$ Consider, for example, the impact of the ratio of short-term bank debt, which we can relate to total bank debt or to the level of reserves. The marginal effect is to raise the spreads in the early years, but

\footnotetext{
${ }^{19}$ Variables whose coefficients we do not report tended to show no significant changes over time over time.
} 
this effect falls after 1994 and turns negative in 1995-97, due to high growth in the region (see the bottom panel of Table 10). An interpretation is that international bankers, while typically cautious of high short-term debt, appear to have been taking an optimistic view in East Asia on account of the ability of borrowers in the region to service the debt through rapid growth. Ultimately, of course, growth expectations declined, and the high short-term debt ratios suddenly came to be seen as unsustainable. ${ }^{20}$

These results make it easier to understand why investors should have become so concerned about the level of short-term debt in various East Asian countries in the mid1990s. While high levels of short-term debt had been characteristic of East Asia for some time, there was a certain knife-edge quality to their sustainability. Rapidly growing firms value the flexibility of short-term loans, while lenders for their part are comforted by the relationship built through rolling over the loans and by the growth prospects for servicing them in the future. But if doubt is cast on the ability to service these loans and their supply is summarily cut off, growth can fall sharply, further depressing confidence in the ability to repay.

\section{Extensions and Sensitivity Analyses}

We explored the robustness of our results in several ways. Our finding that bank lending increases with a rise in the relevant U.S. treasury rates led us to examine the influence of the yield curve. We then focussed on alternative measures of the adequacy of reserves. Finally, for two regions, Latin America and South Asia, where the full set of variables gave somewhat imprecise results, we examined more parsimonious models.

\footnotetext{
${ }^{20}$ This unsustainability is also evident in the behavior over time of reserves to short-term debt. Both the
} mean and the coefficient on the ratio of reserves to short-term debt move to raise spreads: reserves 
Yield curve. An important difference between our results for bank loans and bonds is the different response to U.S. interest rates. While bond issuance appears to fall with the U.S. treasury rate (for ten-year maturity), bank lending appears to rise with the treasury rate (the relevant maturity in this case being three years). The possibility that our different results reflect the use of different interest rates led us to add a measure of the yield curve, the difference between the ten-year and one-year treasury rates. Note from Table 11 that the sign on the yield curve is negative and highly significant, while the sign on the three-year treasury rate now becomes negative (though not significant). In other words, bank lending now appears to increase when three-year treasury rates fall or when the yield curve becomes flatter. ${ }^{21}$ This result points to the possibility that when the yield curve is compressed, expectations of future interest rate increases are dampened, thus increasing the propensity to borrow. The second column of Table 11 suggests that the yield curve shifts do not significantly influence the spreads charged.

Influence of reserves on spreads. The third and fourth columns of Table 11 add the reserves/imports ratio to the spreads equation. The reserves/imports ratio now enters positively, the reserves/short-term debt ratio negatively. The coefficients are almost the same in magnitude, as if when short-term debt increases to finance imports and reserves remain unchanged, then there is no impact on spreads, but that when short-term debt rises for reasons unrelated to a trade transaction, then it raises spreads.

Alternative Latin American and South Asian models. For both Latin America and South Asia, the interaction terms included in the spreads equation were a source of multicollinearity. Moreover, the correlation among the country variables is high. The 
fifth and sixth columns of Table 11 therefore present more parsimonious versions of the Latin American and South Asian spread equations. The results are now consistent with the pattern observed for the full sample and other regions. The coefficients for Latin America also display greater statistical significance. For South Asia, the "wrong" sign on GDP growth disappears and higher growth is seen to produce a statistically significant and quantitatively large reduction in spreads. Thus, the more parsimonious specification, by reducing multicollinearity, eliminates some of the anomalous results reported above. ${ }^{22}$

\section{Conclusion}

Our analysis of spreads charged by international banks to emerging-market borrowers reveals a market that reacts to macroeconomic and financial information in much the same manner as the bond market. The close correspondence between the two sets of empirical results for capital flows intermediated by different institutions is surprising, even striking. Institutional connections between the two markets may help to explain this finding. Banks are sometimes the main subscribers to emerging market bonds, while traditional bond market investors, such as insurance companies and pension funds, increasingly participate in what are misleadingly referred to as bank syndicates. Such convergence will only increase over time as financial mergers bring "bond" and "bank" market participants under one corporate roof.

${ }^{21}$ Since a rise in the three-year rate is typically accompanied by compression of the yield curve, the two different channels of influence are not easy to distinguish.

22 An alternative approach to identifying the cases of non-lending is to consider for each country and each quarter the different industrial sectors as issuers. We grouped the data into five industrial categories, as described above. Thus, each country in each quarter has five potential borrowers. If a loan is observed for any of these borrowers, a "one" is generated; otherwise a "zero" is recorded. This then becomes the basis for the probit and the joint estimation of the probit and the spreads equation. The results remain virtually unchanged. 
That said, the relationship between macroeconomic and financial variables on the one hand and pricing behavior on the other is more stable over time for bank loans than bonds. It is tempting to interpret this in terms of the relatively long period for which bank lending has been underway and the greater maturity of that segment of the capital market.

The large number of small bank loans issued in the 1990s, in comparison with the smaller number of larger bond issues, highlights the role of international bankers in dealing with the ongoing production and trade financing requirements of small borrowers in particular. In other words, international banks continue to play an important role in meeting the external financing needs of their borrowers in ways that the bond market cannot duplicate.

East Asia's special relationship with the international banking system is evident from the raw numbers and from the statistical relationships alike. The evidence points to East Asia's greater historical ability to time its entry and exit from the market. Where borrower heterogeneity is important, East Asian borrowers are seen to benefit from their unobserved credit characteristics.

Is there evidence of growing moral hazard affecting international bank lending? We do see evidence of growing bullishness in the first half of the 1990s by bank lenders to East Asia, which may reflect moral hazard. But on this issue it is fair to say that the jury remains out.

Finally, our results point to the riskiness of high levels of domestic debt. High short-term debt can coexist for extended periods with rapid growth but is liable to unravel if perceptions of sustainability shift. The results thus caution once again excessive dependence on short-term debt. 
Figure 1: Loan versus Bond Primary Market Spreads

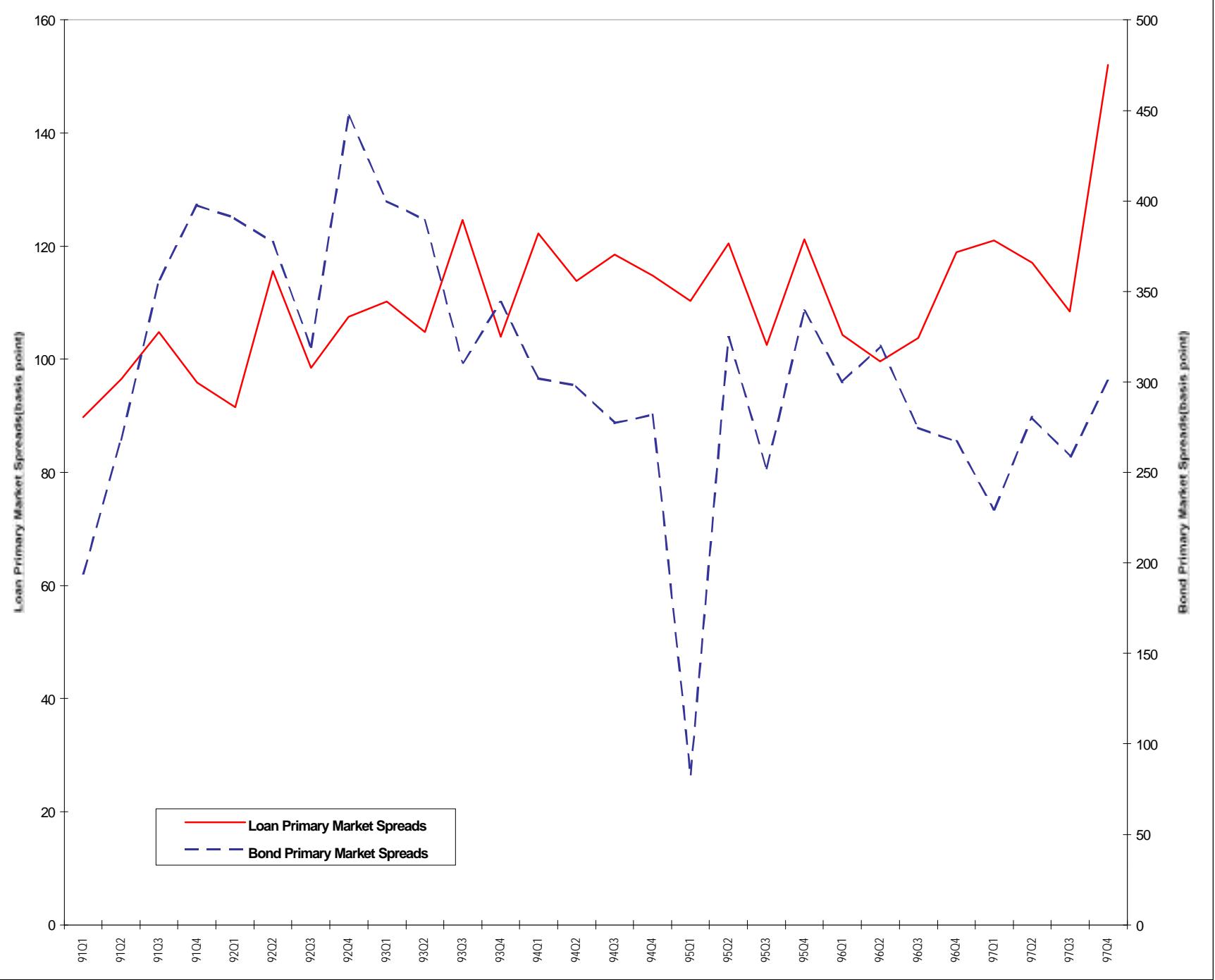


Table 1 Emerging Market Bond Issues and Loan Commitments

(In billions of US dollars)

\begin{tabular}{|c|c|c|c|c|c|c|c|c|c|c|c|c|c|c|}
\hline & \multirow[b]{2}{*}{1991} & \multirow[b]{2}{*}{1992} & \multirow[b]{2}{*}{1993} & \multirow[b]{2}{*}{1994} & \multirow[b]{2}{*}{1995} & \multirow[b]{2}{*}{1996} & \multirow[b]{2}{*}{1997} & \multicolumn{4}{|c|}{1997} & \multicolumn{3}{|c|}{1998} \\
\hline & & & & & & & & Q1 & Q2 & Q3 & $\overline{\mathrm{Q} 4}$ & Q1 & April & May \\
\hline \multicolumn{15}{|l|}{ Bond Issues } \\
\hline Africa & 0.3 & 0.7 & 0.1 & 2.1 & 1.9 & 1.6 & 9.3 & 0.0 & 1.0 & 6.8 & 1.4 & 1.3 & 0.0 & 0.0 \\
\hline Asia & 4.0 & 5.9 & 21.9 & 29.8 & 25.3 & 43.1 & 45.5 & 12.7 & 15.8 & 14.1 & 2.7 & 2.7 & 5.6 & 0.4 \\
\hline Europe & 2.0 & 4.8 & 9.6 & 3.5 & 6.5 & 7.4 & 16.2 & 2.8 & 6.5 & 3.7 & 3.1 & 5.4 & 1.9 & 1.9 \\
\hline W. Hemisphere & 7.0 & 12.9 & 28.7 & 17.9 & 23.0 & 47.1 & 54.1 & 11.8 & 18.7 & 19.7 & 3.8 & 14.7 & 4.5 & 4.0 \\
\hline \multicolumn{15}{|c|}{ Loan Commitments } \\
\hline Emerging Markets & 41.6 & 31.4 & 40.6 & 56.9 & 82.9 & 90.7 & 123.5 & 23.2 & 32.8 & 29.8 & 37.5 & 8.1 & 5.2 & 2.2 \\
\hline Africa & 4.2 & 2.5 & 1.1 & 0.6 & 6.7 & 3.1 & 4.5 & 1.0 & 0.4 & 0.7 & 2.4 & 0.1 & 0.0 & 0.0 \\
\hline
\end{tabular}

IMF (1998)

Table 2 Number of Loan Commitments 1991 - 1997

\begin{tabular}{|c|c|c|c|c|c|c|c|c|c|c|c|c|c|c|c|c|c|c|c|c|}
\hline \multirow[b]{2}{*}{ Year } & \multicolumn{4}{|c|}{ Manufacturing } & \multicolumn{4}{|c|}{ Finance } & \multicolumn{4}{|c|}{ Infrastructure } & \multicolumn{4}{|c|}{ Other Services } & \multicolumn{4}{|c|}{ Government } \\
\hline & $\begin{array}{l}\text { Sover } \\
\text {-eign }\end{array}$ & Public & Private & Total & $\begin{array}{l}\text { Sover } \\
\text {-eign }\end{array}$ & Public & Private & Total & $\begin{array}{l}\text { Sover } \\
\text {-eign }\end{array}$ & Public & Private & Total & $\begin{array}{c}\text { Sover } \\
\text {-eign }\end{array}$ & Public & Private & Total & $\begin{array}{l}\text { Sover } \\
\text {-eign }\end{array}$ & Public & Private & Tota \\
\hline 1991 & 2 & 19 & 26 & 47 & 1 & 16 & 55 & 72 & 3 & 30 & 12 & 45 & 0 & 26 & 36 & 62 & 6 & 39 & 0 & 45 \\
\hline 1992 & 1 & 14 & 30 & 45 & 0 & 25 & 75 & 100 & 3 & 31 & 18 & 52 & 1 & 44 & 27 & 72 & 5 & 35 & 0 & 40 \\
\hline 1993 & 5 & 14 & 37 & 56 & 2 & 37 & 120 & 159 & 2 & 45 & 31 & 78 & 0 & 54 & 38 & 92 & 5 & 37 & 0 & 42 \\
\hline 1994 & 2 & 34 & 94 & 130 & 2 & 52 & 147 & 201 & 0 & 48 & 42 & 90 & 0 & 43 & 55 & 98 & 14 & 54 & 1 & 69 \\
\hline 1996 & 2 & 37 & 246 & 285 & 1 & 85 & 371 & 457 & 6 & 87 & 136 & 229 & 0 & 57 & 139 & 196 & 20 & 71 & 1 & 92 \\
\hline 1997 & 4 & 54 & 230 & 288 & 1 & 113 & 334 & 448 & 2 & 86 & 131 & 219 & 0 & 71 & 140 & 211 & 23 & 66 & 2 & 91 \\
\hline Total & 21 & 198 & 815 & 1034 & 11 & 401 & 1357 & 1769 & 18 & 395 & 466 & 879 & 1 & 340 & 526 & 867 & 88 & 349 & 4 & 441 \\
\hline
\end{tabular}


Table 3 Spreads on Loans and Bonds 1991 - 1997

\begin{tabular}{|c|c|c|c|c|c|c|c|c|}
\hline \multicolumn{9}{|l|}{ Year } \\
\hline$\underline{\text { Region }}$ & $\underline{1991}$ & $\underline{1992}$ & $\underline{1993}$ & $\underline{1994}$ & $\underline{1995}$ & $\underline{1996}$ & $\underline{1997}$ & $\underline{\text { Total }}$ \\
\hline Africa & 153 & 166 & 0 & 130 & 113 & 82 & 82 & 102 \\
\hline Caribbean & 142 & 114 & 115 & 88 & 63 & 82 & 131 & 104 \\
\hline East Asia & 82 & 92 & 95 & 101 & 95 & 94 & 93 & 94 \\
\hline East Europe & 120 & 212 & 230 & 212 & 175 & 188 & 240 & 211 \\
\hline Latin America & 150 & 131 & 178 & 231 & 231 & 165 & 158 & 174 \\
\hline Middle East and North Asia & 113 & 119 & 120 & 140 & 145 & 93 & 104 & 115 \\
\hline West Europe & 71 & 65 & 66 & 46 & 0 & 22 & 24 & 43 \\
\hline All Loans & 98 & 104 & 110 & 117 & 113 & 107 & 121 & 112 \\
\hline All Bonds & 270 & 339 & 354 & 228 & 218 & 240 & 229 & 256 \\
\hline
\end{tabular}

Table 4 Average Spreads on Loans 1991 - 1997

\begin{tabular}{|c|c|c|c|c|c|c|c|c|c|c|c|c|c|c|c|c|c|c|c|c|}
\hline \multirow[b]{2}{*}{ Year } & \multicolumn{4}{|c|}{ Manufacturing } & \multicolumn{4}{|c|}{ Finance } & \multicolumn{4}{|c|}{ Infrastructure } & \multicolumn{4}{|c|}{ Other Services } & \multicolumn{4}{|c|}{ Government } \\
\hline & $\begin{array}{c}\text { Sover } \\
\text {-eign }\end{array}$ & Public & Private & Total & $\begin{array}{r}\text { Sover } \\
\text {-eign }\end{array}$ & Public & Private & Total & $\begin{array}{l}\text { Sover } \\
\text {-eign }\end{array}$ & Public & Private & Total & $\begin{array}{l}\text { Sover } \\
\text {-eign }\end{array}$ & Public & Private & Total & $\begin{array}{r}\text { Sover } \\
\text {-eign }\end{array}$ & Public & Private & Total \\
\hline 1991 & 110 & 117 & 139 & 128 & 100 & 66 & 83 & 79 & 91 & 102 & 108 & 103 & 0 & 90 & 115 & 104 & 73 & 80 & 0 & 79 \\
\hline 1992 & 130 & 92 & 115 & 108 & 0 & 84 & 89 & 88 & 30 & 116 & 137 & 118 & 81 & 109 & 130 & 117 & 173 & 89 & 0 & 99 \\
\hline 1993 & 104 & 114 & 120 & 117 & 130 & 84 & 95 & 93 & 138 & 107 & 184 & 138 & 0 & 106 & 132 & 117 & 90 & 96 & 0 & 96 \\
\hline 1994 & 172 & 124 & 148 & 142 & 99 & 120 & 93 & 100 & 0 & 113 & 123 & 118 & 0 & 104 & 137 & 122 & 94 & 103 & 140 & 102 \\
\hline 1995 & 140 & 124 & 150 & 146 & 105 & 75 & 91 & 87 & 86 & 117 & 124 & 121 & 0 & 98 & 142 & 128 & 122 & 104 & 0 & 108 \\
\hline 1996 & 114 & 98 & 114 & 112 & 45 & 94 & 102 & 101 & 87 & 102 & 120 & 112 & 0 & 83 & 119 & 108 & 125 & 93 & 124 & 101 \\
\hline 1997 & 102 & 119 & 110 & 111 & 70 & 141 & 130 & 133 & 42 & 124 & 115 & 118 & 0 & 85 & 145 & 125 & 141 & 93 & 95 & 105 \\
\hline Total & 121 & 114 & 125 & 123 & 99 & 105 & 104 & 104 & 79 & 112 & 124 & 118 & 81 & 95 & 133 & 118 & 121 & 94 & 113 & 100 \\
\hline
\end{tabular}


Table 5 The Maturity (in years) of International Loans 1991 - 1997

\begin{tabular}{|c|c|c|c|c|c|c|c|c|c|c|c|c|c|c|c|c|c|c|c|c|}
\hline \multirow[b]{2}{*}{ Year } & \multicolumn{4}{|c|}{ Manufacturing } & \multicolumn{4}{|c|}{ Finance } & \multicolumn{4}{|c|}{ Infrastructure } & \multicolumn{4}{|c|}{ Other Services } & \multicolumn{4}{|c|}{ Government } \\
\hline & $\begin{array}{l}\text { Sover } \\
\text {-eign }\end{array}$ & Public & Private & Total & $\begin{array}{l}\text { Sover } \\
\text {-eign }\end{array}$ & Public & Private & Total & $\begin{array}{l}\text { Sover } \\
\text {-eign }\end{array}$ & Public & Private & Total & $\begin{array}{c}\text { Sover } \\
\text {-eign }\end{array}$ & Public & Private & Total & $\begin{array}{l}\text { Sover } \\
\text {-eign }\end{array}$ & Public & Private & Total \\
\hline 1991 & 1.0 & 4.4 & 5.8 & 5.0 & 4.0 & 4.7 & 2.4 & 3.0 & 7.7 & 6.7 & 9.9 & 7.7 & 0.0 & 8.2 & 4.3 & 5.9 & 6.1 & 5.5 & 0.0 & 5.6 \\
\hline 1992 & 1.0 & 6.0 & 6.4 & 6.1 & 0.0 & 3.9 & 2.8 & 3.1 & 12.2 & 6.2 & 8.6 & 7.4 & 4.0 & 7.3 & 5.0 & 6.4 & 3.8 & 5.4 & 0.0 & 5.2 \\
\hline 1993 & 1.6 & 4.5 & 4.3 & 4.1 & 11.0 & 5.2 & 2.9 & 3.6 & 7.5 & 4.9 & 9.1 & 6.6 & 0.0 & 7.7 & 3.9 & 6.1 & 8.3 & 4.7 & 0.0 & 5.1 \\
\hline 1995 & 0.9 & 4.7 & 4.6 & 4.5 & 3.5 & 5.0 & 3.8 & 4.0 & 3.0 & 5.3 & 8.1 & 6.9 & 0.0 & 7.7 & 4.5 & 5.6 & 6.7 & 3.8 & 0.0 & 4.5 \\
\hline 1996 & 2.0 & 4.4 & 5.2 & 5.1 & 3.0 & 3.9 & 3.6 & 3.7 & 3.0 & 4.5 & 6.6 & 5.7 & 0.0 & 4.7 & 4.4 & 4.5 & 4.8 & 3.6 & 3.0 & 3.9 \\
\hline 1997 & 1.0 & 4.9 & 5.0 & 4.9 & 5.0 & 3.5 & 3.4 & 3.4 & 6.2 & 4.7 & 6.5 & 5.8 & 0.0 & 5.4 & 4.5 & 4.8 & 3.8 & 3.9 & 4.0 & 3.9 \\
\hline Total & 1.3 & 4.6 & 4.9 & 4.8 & 5.3 & 4.3 & 3.5 & 3.7 & 6.2 & 5.0 & 7.3 & 6.2 & 4.0 & 6.6 & 4.3 & 5.2 & 5.3 & 4.2 & 3.0 & 4.4 \\
\hline
\end{tabular}


Table 6: Spreads on Primary Loan issues: Descriptive Regressions (t-statistics in parentheses)

\begin{tabular}{|c|c|c|c|c|}
\hline Log amount & $\begin{array}{l}-0.079 \\
(-8.412)\end{array}$ & $\begin{array}{l}-0.079 \\
(-8.687)\end{array}$ & $\begin{array}{c}-0.079 \\
(-8.690)\end{array}$ & $\begin{array}{l}-0.072 \\
(-7.804)\end{array}$ \\
\hline Maturity & $\begin{array}{c}0.008 \\
(2.760)\end{array}$ & $\begin{array}{c}0.008 \\
(3.084)\end{array}$ & $\begin{array}{c}0.009 \\
(3.228)\end{array}$ & $\begin{array}{c}0.002 \\
(0.810)\end{array}$ \\
\hline $\begin{array}{l}\text { Log of } 3 \text { Year US. Treasury } \\
\text { Rate }\end{array}$ & $\begin{array}{l}-0.202 \\
(-2.881)\end{array}$ & $\begin{array}{l}-0.168 \\
(-2.452)\end{array}$ & $\begin{array}{l}-0.166 \\
(-2.425)\end{array}$ & $\begin{array}{l}-0.172 \\
(-2.513)\end{array}$ \\
\hline Dummy for Private Borrower & $\begin{array}{c}0.064 \\
(3.245)\end{array}$ & $\begin{array}{c}0.010 \\
(0.535)\end{array}$ & $\begin{array}{l}0.008 \\
(0.435)\end{array}$ & $\begin{array}{c}0.033 \\
(1.541)\end{array}$ \\
\hline Dummy for Latin America & $\begin{array}{c}0.481 \\
(14.666)\end{array}$ & $\begin{array}{c}0.435 \\
(13.550)\end{array}$ & $\begin{array}{c}0.430 \\
(13.338)\end{array}$ & $\begin{array}{c}0.379 \\
(11.371)\end{array}$ \\
\hline Number of Borrowings & & $\begin{array}{c}-0.025 \\
(-16.220)\end{array}$ & $\begin{array}{c}-0.025 \\
(-16.186)\end{array}$ & $\begin{array}{c}-0.026 \\
(-16.637)\end{array}$ \\
\hline YEN Issue & & & $\begin{array}{l}-0.359 \\
(-5.095)\end{array}$ & $\begin{array}{l}-0.345 \\
(-4.806)\end{array}$ \\
\hline Deutsche Mark Issue & & & $\begin{array}{c}-0.079 \\
(-1.267)\end{array}$ & $\begin{array}{l}-0.062 \\
(-1.002)\end{array}$ \\
\hline Dummy for Supranational & & & $\begin{array}{l}-0.303 \\
(-0.941)\end{array}$ & $\begin{array}{l}-0.107 \\
(-0.333)\end{array}$ \\
\hline \multicolumn{5}{|l|}{ Industrial Sectors } \\
\hline $\begin{array}{l}\text { Dummy for } \\
\text { Manufacturing Sector }\end{array}$ & & & & $\begin{array}{c}-0.053 \\
(-1.722)\end{array}$ \\
\hline $\begin{array}{l}\text { Dummy for Financial } \\
\text { Services Sector }\end{array}$ & & & & $\begin{array}{l}-0.209 \\
(-7.297)\end{array}$ \\
\hline $\begin{array}{l}\text { Dummy for Other } \\
\text { Services }\end{array}$ & & & & $\begin{array}{l}-0.010 \\
(-0.332)\end{array}$ \\
\hline $\begin{array}{l}\text { Dummy for } \\
\text { Government }\end{array}$ & & & & $\begin{array}{l}-0.107 \\
(-2.721)\end{array}$ \\
\hline Constant & $\begin{array}{c}5.036 \\
(38.816)\end{array}$ & $\begin{array}{c}5.114 \\
(40.404)\end{array}$ & $\begin{array}{c}5.118 \\
(40.514)\end{array}$ & $\begin{array}{c}5.223 \\
(40.469)\end{array}$ \\
\hline Number of observations & 5010 & 5010 & 5010 & 4888 \\
\hline Adjusted R-squared & 0.051 & 0.098 & 0.103 & 0.118 \\
\hline
\end{tabular}




\section{Table 7: Influence of Country Characteristics on Loan Spreads (OLS Regressions, t-statistics in parentheses)}

\begin{tabular}{|c|c|c|c|c|c|}
\hline Log amount & $\begin{array}{c}-0.087 \\
(-10.178)\end{array}$ & $\begin{array}{c}-0.092 \\
(-10.796)\end{array}$ & $\begin{array}{c}-0.092 \\
(-10.646)\end{array}$ & $\begin{array}{l}-0.078 \\
(-9.284)\end{array}$ & $\begin{array}{c}-0.078 \\
(-9.276)\end{array}$ \\
\hline Maturity & $\begin{array}{c}0.018 \\
(6.766)\end{array}$ & $\begin{array}{c}0.019 \\
(7.447)\end{array}$ & $\begin{array}{c}0.020 \\
(7.853)\end{array}$ & $\begin{array}{c}0.019 \\
(7.714)\end{array}$ & $\begin{array}{c}0.020 \\
(7.810)\end{array}$ \\
\hline $\begin{array}{l}\text { Log of } 3 \text { Year US. Treasury } \\
\text { Rate }\end{array}$ & $\begin{array}{c}-0.211 \\
(-3.377)\end{array}$ & $\begin{array}{c}-0.147 \\
(-2.357)\end{array}$ & $\begin{array}{l}-0.155 \\
(-2.495)\end{array}$ & $\begin{array}{l}-0.100 \\
(-1.649)\end{array}$ & $\begin{array}{c}-0.088 \\
(-1.450)\end{array}$ \\
\hline Dummy for Private Borrower & $\begin{array}{c}0.225 \\
(10.707)\end{array}$ & $\begin{array}{c}0.195 \\
(9.183)\end{array}$ & $\begin{array}{l}0.195 \\
(9.117)\end{array}$ & $\begin{array}{c}0.225 \\
(10.732)\end{array}$ & $\begin{array}{c}0.218 \\
(10.381)\end{array}$ \\
\hline Dummy for Latin America & $\begin{array}{c}0.142 \\
(3.889)\end{array}$ & $\begin{array}{c}0.157 \\
(4.350)\end{array}$ & $\begin{array}{l}0.120 \\
(3.324)\end{array}$ & $\begin{array}{c}0.112 \\
(3.162)\end{array}$ & $\begin{array}{c}0.071 \\
(1.978)\end{array}$ \\
\hline Number of Borrowings & $\begin{array}{c}-0.012 \\
(-8.819)\end{array}$ & $\begin{array}{c}-0.013 \\
(-9.130)\end{array}$ & $\begin{array}{l}-0.013 \\
(-9.040)\end{array}$ & $\begin{array}{l}-0.052 \\
(-6.935)\end{array}$ & $\begin{array}{l}-0.053 \\
(-7.171)\end{array}$ \\
\hline \multicolumn{6}{|l|}{ Country Characteristics } \\
\hline Credit Rating Residual & $\begin{array}{c}-0.024 \\
(-24.914)\end{array}$ & $\begin{array}{c}-0.028 \\
(-26.447)\end{array}$ & $\begin{array}{c}-0.027 \\
(-24.692)\end{array}$ & $\begin{array}{c}-0.026 \\
(-23.990)\end{array}$ & $\begin{array}{c}-0.022 \\
(-17.411)\end{array}$ \\
\hline Debt/GNP & $\begin{array}{c}0.451 \\
(7.185)\end{array}$ & $\begin{array}{c}0.462 \\
(7.233)\end{array}$ & $\begin{array}{c}0.469 \\
(7.358)\end{array}$ & $\begin{array}{c}0.600 \\
(9.473)\end{array}$ & $\begin{array}{c}0.632 \\
(9.981)\end{array}$ \\
\hline $\begin{array}{l}\text { Dummy for Debt } \\
\text { Rescheduling }\end{array}$ & $\begin{array}{c}0.552 \\
(14.091)\end{array}$ & $\begin{array}{c}0.536 \\
(13.468)\end{array}$ & $\begin{array}{c}0.532 \\
(13.276)\end{array}$ & $\begin{array}{c}0.461 \\
(11.734)\end{array}$ & $\begin{array}{c}0.403 \\
(10.005)\end{array}$ \\
\hline Debt Service/Exports & $\begin{array}{c}0.416 \\
(4.675)\end{array}$ & $\begin{array}{c}0.396 \\
(4.220)\end{array}$ & $\begin{array}{c}0.502 \\
(5.214)\end{array}$ & $\begin{array}{c}0.673 \\
(7.112)\end{array}$ & $\begin{array}{c}0.643 \\
(6.815)\end{array}$ \\
\hline GDP Growth & $\begin{array}{l}-12.591 \\
(-10.330)\end{array}$ & $\begin{array}{l}-11.413 \\
(-9.349)\end{array}$ & $\begin{array}{l}-11.357 \\
(-9.080)\end{array}$ & $\begin{array}{l}-20.237 \\
(-4.352)\end{array}$ & $\begin{array}{l}-15.153 \\
(-3.221)\end{array}$ \\
\hline $\begin{array}{l}\text { Standard Deviation of } \\
\text { Export Growth }\end{array}$ & $\begin{array}{c}0.555 \\
(6.156)\end{array}$ & $\begin{array}{c}0.724 \\
(7.692)\end{array}$ & $\begin{array}{l}0.714 \\
(7.551)\end{array}$ & $\begin{array}{c}0.443 \\
(4.684)\end{array}$ & $\begin{array}{c}0.348 \\
(3.643)\end{array}$ \\
\hline Reserves/Short Term Debt & & $\begin{array}{l}-0.052 \\
(-7.672)\end{array}$ & $\begin{array}{l}-0.047 \\
(-6.884)\end{array}$ & $\begin{array}{l}-0.044 \\
(-6.471)\end{array}$ & $\begin{array}{c}-0.040 \\
(-5.853)\end{array}$ \\
\hline $\begin{array}{l}\text { Ratio of Short Term } \\
\text { Debt to Total Debt }\end{array}$ & & $\begin{array}{c}0.111 \\
(1.268)\end{array}$ & $\begin{array}{l}0.057 \\
(0.575)\end{array}$ & $\begin{array}{c}0.842 \\
(4.635)\end{array}$ & $\begin{array}{l}0.967 \\
(5.312)\end{array}$ \\
\hline $\begin{array}{l}\text { Ratio of Domestic } \\
\text { Credit to GDP }\end{array}$ & & & $\begin{array}{l}-0.002 \\
(-0.301)\end{array}$ & $\begin{array}{c}-0.212 \\
(-12.911)\end{array}$ & $\begin{array}{c}-0.390 \\
(-11.751)\end{array}$ \\
\hline $\begin{array}{l}\text { Number of Borrowing* } \\
\text { Ratio of Short Term } \\
\text { Debt to Total Debt }\end{array}$ & & & & $\begin{array}{l}0.065 \\
(5.474)\end{array}$ & $\begin{array}{l}0.067 \\
(5.686)\end{array}$ \\
\hline $\begin{array}{l}\text { GDP Growth * Ratio of } \\
\text { Short Term Debt to } \\
\text { Total Debt }\end{array}$ & & & & $\begin{array}{l}-38.088 \\
(-4.141)\end{array}$ & $\begin{array}{l}-47.338 \\
(-5.099)\end{array}$ \\
\hline $\begin{array}{l}\text { GDP Growth * Ratio of } \\
\text { Domestic Credit to GDP }\end{array}$ & & & & $\begin{array}{c}14.672 \\
(14.893)\end{array}$ & $\begin{array}{c}16.637 \\
(16.126)\end{array}$ \\
\hline $\begin{array}{l}\text { Ratio of Domestic } \\
\text { Credit to GDP* Ratio of } \\
\text { Domestic Credit to GDP }\end{array}$ & & & & & $\begin{array}{c}0.022 \\
(6.163)\end{array}$ \\
\hline Constant & $\begin{array}{c}5.068 \\
(40.433)\end{array}$ & $\begin{array}{c}4.976 \\
(35.927)\end{array}$ & $\begin{array}{c}4.988 \\
(35.893)\end{array}$ & $\begin{array}{c}4.712 \\
(30.409)\end{array}$ & $\begin{array}{c}4.793 \\
(30.946)\end{array}$ \\
\hline Number of observations & 4656 & 4650 & 4551 & 4551 & 4551 \\
\hline Adjusted R-squared & 0.327 & 0.338 & 0.345 & 0.380 & 0.385 \\
\hline
\end{tabular}

Note: All regressions include dummies for industrial sectors, currencies of denomination, and supranational as defined in table 6 . 


\section{Table 8: Determinants of the Probability of a Loan Issue (t-statistics in parentheses)}

\begin{tabular}{|c|c|c|c|c|c|c|}
\hline & All & East Asia & Latin America & East Europe & East Europe & South Asia \\
\hline $\begin{array}{l}\log \text { of } 3 \text { Year US. } \\
\text { Treasury Rate }\end{array}$ & $\begin{array}{c}0.154 \\
(3.370)\end{array}$ & $\begin{array}{l}0.008 \\
(0.360)\end{array}$ & $\begin{array}{c}0.283 \\
(3.380)\end{array}$ & $\begin{array}{c}0.163 \\
(0.860)\end{array}$ & $\begin{array}{l}0.122 \\
(0.640)\end{array}$ & $\begin{array}{c}0.390 \\
(1.750)\end{array}$ \\
\hline $\begin{array}{l}\text { Dummy for Private } \\
\text { Borrower }\end{array}$ & $\begin{array}{c}0.331 \\
(25.090)\end{array}$ & $\begin{array}{c}0.194 \\
(17.620)\end{array}$ & $\begin{array}{c}0.310 \\
(12.610)\end{array}$ & $\begin{array}{c}0.279 \\
(6.730)\end{array}$ & $\begin{array}{c}0.279 \\
(6.760)\end{array}$ & $\begin{array}{c}0.081 \\
(1.280)\end{array}$ \\
\hline Dummy for Latin America & $\begin{array}{c}-0.380 \\
(-17.580)\end{array}$ & & & & & \\
\hline Credit Rating Residual & $\begin{array}{c}0.014 \\
(20.100)\end{array}$ & $\begin{array}{c}0.006 \\
(11.050)\end{array}$ & $\begin{array}{c}0.017 \\
(10.930)\end{array}$ & $\begin{array}{c}0.010 \\
(3.180)\end{array}$ & $\begin{array}{c}0.014 \\
(5.380)\end{array}$ & $\begin{array}{c}0.002 \\
(0.200)\end{array}$ \\
\hline Debt/GNP & $\begin{array}{c}-1.038 \\
(-26.620)\end{array}$ & $\begin{array}{c}-0.292 \\
(-8.490)\end{array}$ & $\begin{array}{c}-0.254 \\
(-3.880)\end{array}$ & $\begin{array}{l}-1.209 \\
(-3.670)\end{array}$ & $\begin{array}{l}-1.316 \\
(-4.010)\end{array}$ & $\begin{array}{l}-1.729 \\
(-4.34)\end{array}$ \\
\hline $\begin{array}{l}\text { Dummy for Debt } \\
\text { Rescheduling }\end{array}$ & $\begin{array}{l}-0.107 \\
(-4.630)\end{array}$ & $\begin{array}{l}-0.121 \\
(-4.900)\end{array}$ & $\begin{array}{l}-0.114 \\
(-4.720)\end{array}$ & $\begin{array}{c}0.194 \\
(2.780)\end{array}$ & & \\
\hline Debt Service /Exports & $\begin{array}{c}0.909 \\
(15.080)\end{array}$ & $\begin{array}{l}-0.002 \\
(-0.030)\end{array}$ & $\begin{array}{c}0.525 \\
(7.920)\end{array}$ & $\begin{array}{c}0.354 \\
(1.440)\end{array}$ & $\begin{array}{l}0.290 \\
(1.170)\end{array}$ & $\begin{array}{c}1.341 \\
(1.520)\end{array}$ \\
\hline Reserves/Imports & $\begin{array}{c}0.044 \\
(5.950)\end{array}$ & $\begin{array}{l}0.060 \\
(7.890)\end{array}$ & $\begin{array}{c}0.139 \\
(10.290)\end{array}$ & $\begin{array}{l}0.401 \\
(7.550)\end{array}$ & $\begin{array}{l}0.404 \\
(7.580)\end{array}$ & $\begin{array}{l}0.455 \\
(7.390)\end{array}$ \\
\hline Reserves/Short term Debt & $\begin{array}{l}-0.005 \\
(-3.820)\end{array}$ & $\begin{array}{c}-0.051 \\
(-12.100)\end{array}$ & $\begin{array}{c}-0.062 \\
(-3.480)\end{array}$ & $\begin{array}{l}-0.006 \\
(-3.830)\end{array}$ & $\begin{array}{l}-0.007 \\
(-4.760)\end{array}$ & $\begin{array}{l}-0.113 \\
(-3.400)\end{array}$ \\
\hline $\begin{array}{l}\text { Ratio of Short Term Debt } \\
\text { to Total Debt }\end{array}$ & $\begin{array}{c}-0.267 \\
(-5.640)\end{array}$ & $\begin{array}{c}-0.668 \\
(-16.250)\end{array}$ & $\begin{array}{l}-0.183 \\
(-1.870)\end{array}$ & $\begin{array}{c}0.279 \\
(1.360)\end{array}$ & $\begin{array}{l}0.530 \\
(2.900)\end{array}$ & $\begin{array}{c}1.341 \\
(3.290)\end{array}$ \\
\hline $\begin{array}{l}\text { Ratio of Domestic Credit to } \\
\text { GDP }\end{array}$ & $\begin{array}{c}0.086 \\
(12.580)\end{array}$ & $\begin{array}{c}0.019 \\
(4.320)\end{array}$ & $\begin{array}{l}0.020 \\
(1.300)\end{array}$ & $\begin{array}{l}-0.027 \\
(-0.560)\end{array}$ & $\begin{array}{l}-0.114 \\
(-3.060)\end{array}$ & $\begin{array}{l}1.270 \\
(2.260)\end{array}$ \\
\hline Number of observations & 8055 & 3623 & 1485 & 684 & 684 & 588 \\
\hline Pseudo R-squared & 0.357 & 0.338 & 0.428 & 0.187 & 0.179 & 0.571 \\
\hline
\end{tabular}

Note: Coefficients reported are the changes in the probability of an infinitesimal change in each independent, continuous variable and, by default, the discrete change in the probability for dummy variable 


\section{Table 9a: Determinants of Spreads with Selectivity Correction (t-statistics in parentheses)}

\begin{tabular}{|c|c|c|c|c|c|}
\hline & All & Asia & Latin America & East Europe & South Asia \\
\hline Log Amount & $\begin{array}{c}-0.077 \\
(-9.240)\end{array}$ & $\begin{array}{l}-0.0852 \\
(-9.273)\end{array}$ & $\begin{array}{c}-0.024 \\
(-0.636)\end{array}$ & $\begin{array}{l}-0.166 \\
(-4.904)\end{array}$ & $\begin{array}{c}.004 \\
(0.120)\end{array}$ \\
\hline Maturity & $\begin{array}{c}0.020 \\
(7.854)\end{array}$ & $\begin{array}{c}0.021 \\
(7.868)\end{array}$ & $\begin{array}{c}-0.014 \\
(-1.101)\end{array}$ & $\begin{array}{c}0.049 \\
(3.766)\end{array}$ & $\begin{array}{c}0.047 \\
(4.689)\end{array}$ \\
\hline Log of 3 Year US. Treasury Rate & $\begin{array}{c}-0.100 \\
(-1.631)\end{array}$ & $\begin{array}{c}-0.140 \\
(-2.133)\end{array}$ & $\begin{array}{c}0.593 \\
(1.699)\end{array}$ & $\begin{array}{c}-0.268 \\
(-0.773)\end{array}$ & $\begin{array}{c}0.183 \\
(0.723)\end{array}$ \\
\hline Dummy for Private Borrower & $\begin{array}{c}0.192 \\
(6.561)\end{array}$ & $\begin{array}{c}0.108 \\
(2.708)\end{array}$ & $\begin{array}{c}0.151 \\
(1.335)\end{array}$ & $\begin{array}{c}0.403 \\
(4.735)\end{array}$ & $\begin{array}{c}0.349 \\
(4.286)\end{array}$ \\
\hline Dummy for Latin America & $\begin{array}{c}0.090 \\
(2.276)\end{array}$ & & & & \\
\hline Number of Borrowing & $\begin{array}{l}-0.054 \\
(-7.257)\end{array}$ & $\begin{array}{c}-0.033 \\
(-3.596)\end{array}$ & $\begin{array}{l}-0.196 \\
(-2.102)\end{array}$ & $\begin{array}{c}0.021 \\
(0.254)\end{array}$ & $\begin{array}{l}-0.013 \\
(-0.344)\end{array}$ \\
\hline Credit Rating Residual & $\begin{array}{c}-0.023 \\
(-15.622)\end{array}$ & $\begin{array}{c}-0.027 \\
(-11.583)\end{array}$ & $\begin{array}{c}-0.014 \\
(-1.912)\end{array}$ & $\begin{array}{l}-0.043 \\
(-5.435)\end{array}$ & $\begin{array}{c}-0.004 \\
(-0.215)\end{array}$ \\
\hline Debt/GNP & $\begin{array}{c}0.712 \\
(7.816)\end{array}$ & $\begin{array}{l}0.346 \\
(2.415)\end{array}$ & $\begin{array}{c}0.088 \\
(0.223)\end{array}$ & $\begin{array}{c}0.632 \\
(0.847)\end{array}$ & $\begin{array}{l}3.147 \\
(4.274)\end{array}$ \\
\hline $\begin{array}{l}\text { Dummy for Debt } \\
\text { Rescheduling }\end{array}$ & $\begin{array}{c}0.418 \\
(10.014)\end{array}$ & $\begin{array}{c}0.082 \\
(1.163)\end{array}$ & $\begin{array}{c}-0.135 \\
(-1.114)\end{array}$ & $\begin{array}{c}0.711 \\
(3.881)\end{array}$ & \\
\hline Debt Service/Exports & $\begin{array}{c}0.582 \\
(5.366)\end{array}$ & $\begin{array}{l}1.912 \\
(8.248)\end{array}$ & $\begin{array}{c}0.125 \\
(0.453)\end{array}$ & $\begin{array}{c}1.872 \\
(3.450)\end{array}$ & $\begin{array}{l}5.246 \\
(3.253)\end{array}$ \\
\hline GDP Growth & $\begin{array}{l}-14.666 \\
(-3.126)\end{array}$ & $\begin{array}{l}-6.535 \\
(-0.558)\end{array}$ & $\begin{array}{l}29.298 \\
(1.240)\end{array}$ & $\begin{array}{l}29.373 \\
(1.275)\end{array}$ & $\begin{array}{c}348.086 \\
(1.543)\end{array}$ \\
\hline Standard Deviation of Export Growth & $\begin{array}{l}0.356 \\
(3.735)\end{array}$ & $\begin{array}{c}0.503 \\
(4.854)\end{array}$ & $\begin{array}{c}1.510 \\
(1.682)\end{array}$ & $\begin{array}{c}1.639 \\
(3.344)\end{array}$ & $\begin{array}{c}0.856 \\
(1.126)\end{array}$ \\
\hline Reserves/Short Term Debt & $\begin{array}{c}-0.036 \\
(-5.132)\end{array}$ & $\begin{array}{c}-0.015 \\
(-1.245)\end{array}$ & $\begin{array}{c}-0.044 \\
(-0.616)\end{array}$ & $\begin{array}{c}-0.052 \\
(-3.003)\end{array}$ & $\begin{array}{c}0.019 \\
(0.372)\end{array}$ \\
\hline $\begin{array}{l}\text { Ratio of Short Term } \\
\text { Debt to Total Debt }\end{array}$ & $\begin{array}{l}1.028 \\
(5.543)\end{array}$ & $\begin{array}{c}0.442 \\
(0.940)\end{array}$ & $\begin{array}{c}.887 \\
(1.234)\end{array}$ & $\begin{array}{c}1.573 \\
(1.632)\end{array}$ & $\begin{array}{l}-3.102 \\
(-2.057)\end{array}$ \\
\hline $\begin{array}{l}\text { Ratio of Domestic } \\
\text { Credit to GDP }\end{array}$ & $\begin{array}{c}-0.393 \\
(-11.727)\end{array}$ & $\begin{array}{c}0.109 \\
(1.275)\end{array}$ & $\begin{array}{l}-0.105 \\
(-0.554)\end{array}$ & $\begin{array}{l}-1.280 \\
(-3.242)\end{array}$ & $\begin{array}{l}31.178 \\
(1.537)\end{array}$ \\
\hline $\begin{array}{l}\text { Ratio of Domestic } \\
\text { Credit to GDP* Ratio of } \\
\text { Domestic Credit to GDP }\end{array}$ & $\begin{array}{c}0.022 \\
(6.171)\end{array}$ & $\begin{array}{c}-0.014 \\
(-1.676)\end{array}$ & $\begin{array}{c}0.012 \\
(0.853)\end{array}$ & $\begin{array}{c}0.496 \\
(3.755)\end{array}$ & $\begin{array}{l}-13.099 \\
(-1.311)\end{array}$ \\
\hline $\begin{array}{l}\text { Number of Borrowing } \\
\text { Ratio of Short Term } \\
\text { Debt to Total Debt }\end{array}$ & $\begin{array}{c}0.068 \\
(5.761)\end{array}$ & $\begin{array}{c}0.037 \\
(2.646)\end{array}$ & $\begin{array}{c}0.244 \\
(1.492)\end{array}$ & $\begin{array}{c}-0.079 \\
(-0.388)\end{array}$ & $\begin{array}{l}-0.022 \\
(-0.250)\end{array}$ \\
\hline $\begin{array}{l}\text { GDP Growth * Ratio of } \\
\text { Short Term Debt to } \\
\text { Total Debt }\end{array}$ & $\begin{array}{l}-47.930 \\
(-5.181)\end{array}$ & $\begin{array}{l}--23.843 \\
(-1.282)\end{array}$ & $\begin{array}{l}-18.210 \\
(-0.403)\end{array}$ & $\begin{array}{c}-130.096 \\
(-1.853)\end{array}$ & $\begin{array}{c}224.259 \\
(1.889)\end{array}$ \\
\hline $\begin{array}{l}\text { GDP Growth * Ratio of } \\
\text { Domestic Credit to GDP }\end{array}$ & $\begin{array}{c}16.467 \\
(15.966)\end{array}$ & $\begin{array}{c}1.128 \\
(0.475)\end{array}$ & $\begin{array}{l}-28.947 \\
(-2.582)\end{array}$ & $\begin{array}{l}-11.860 \\
(-1.449)\end{array}$ & $\begin{array}{l}-444.711 \\
(-2.081)\end{array}$ \\
\hline Constant & $\begin{array}{c}4.814 \\
(30.448)\end{array}$ & $\begin{array}{c}4.642 \\
(15.626)\end{array}$ & $\begin{array}{c}3.643 \\
(3.642)\end{array}$ & $\begin{array}{c}4.509 \\
(4.855)\end{array}$ & $\begin{array}{l}-15.586 \\
(-1.464)\end{array}$ \\
\hline Lambda & $\begin{array}{c}-0.062 \\
(-1.171)\end{array}$ & $\begin{array}{l}-0.203 \\
(-2.217)\end{array}$ & $\begin{array}{c}0.126 \\
(1.091)\end{array}$ & $\begin{array}{c}0.332 \\
(4.218)\end{array}$ & $\begin{array}{c}0.238 \\
(3.766)\end{array}$ \\
\hline Number of loans & 4551 & 3100 & 443 & 287 & 319 \\
\hline Log likelihood & -6936.000 & -2888.684 & -977.150 & -559.022 & -351.951 \\
\hline
\end{tabular}

Note: all regressions include dummies for industrial sectors, currency of denominations and supranational as defined in table 6 . 
Table 9b: Marginal effects, evaluated at the mean values

\begin{tabular}{lccccc} 
& All & East Asia & $\begin{array}{c}\text { Latin } \\
\text { America }\end{array}$ & East Europe & South Asia \\
\hline GDP Growth & -14.366 & -18.708 & -12.604 & -35.362 & 78.179 \\
$\begin{array}{l}\text { Ratio of Short Term } \\
\text { Debt to Total Debt }\end{array}$ & 0.844 & 0.173 & 1.255 & 2.866 & -0.435 \\
$\begin{array}{l}\text { Ratio of Domestic } \\
\text { Credit to GDP }\end{array}$ & -0.198 & 0.089 & -0.398 & -0.787 & 14.217 \\
\end{tabular}

Table 10: Rolling Regressions: East Asia

\section{Part I: Means and Standard Deviations (in parentheses)}

$\begin{array}{lcccc} & 1991-94 & 1994-97 & 1995-96 & 1996-97: 2 \\ & & & & \\ \text { GDP Growth } & 0.020 & 0.018 & 0.018 & 0.016 \\ & (0.007) & (0.005) & (0.005) & (0.004) \\ & & & & \\ \begin{array}{l}\text { Ratio of Short Term } \\ \text { Debt to Total Debt }\end{array} & 0.636 & 0.660 & 0.664 & 0.658 \\ & (0.202) & (0.142) & (0.140) & (0.124) \\ \begin{array}{l}\text { Ratio of Reserves to } \\ \text { Short-term debt }\end{array} & 2.609 & 1.867 & & \\ & (6.590) & (3.823) & (2.995) & 1.700 \\ \begin{array}{l}\text { Ratio of Domestic } \\ \text { Credit to GDP }\end{array} & 2.654 & 3.071 & & \\ & (1.114) & (1.368) & (1.985) & 3.140 \\ & & & & (1.384)\end{array}$

\section{Part II: Marginal effects, evaluated at the mean values}

\begin{tabular}{|c|c|c|c|c|}
\hline & 1991-94 & $1994-97$ & $1995-96$ & $1996-97: 2$ \\
\hline GDP Growth & -20.03 & -12.94 & -10.85 & -4.58 \\
\hline $\begin{array}{l}\text { Ratio of Short Term } \\
\text { Debt to Total Debt }\end{array}$ & 0.19 & -0.07 & -0.59 & -1.00 \\
\hline $\begin{array}{l}\text { Ratio of Reserves to } \\
\text { Short-term debt }\end{array}$ & -0.011 & -0.037 & -0.057 & -0.080 \\
\hline $\begin{array}{l}\text { Ratio of Domestic } \\
\text { Credit to GDP }\end{array}$ & 0.28 & 0.11 & 0.05 & 0.10 \\
\hline
\end{tabular}


Table 11: Sensitivity Analyses

(t-statistics in parentheses)

\begin{tabular}{|c|c|c|c|c|c|c|}
\hline & $\begin{array}{l}\text { Probit } \\
\text { (all) }\end{array}$ & $\begin{array}{l}\text { Spread } \\
\text { (all) }\end{array}$ & $\begin{array}{l}\text { Spread } \\
\text { (all) }\end{array}$ & $\begin{array}{l}\text { Spread } \\
\text { (all) }\end{array}$ & $\begin{array}{l}\text { Spread } \\
\text { (Latin America) }\end{array}$ & $\begin{array}{c}\text { Spread } \\
\text { (South Asia) }\end{array}$ \\
\hline Log amount & & $\begin{array}{c}-0.077 \\
(-9.088)\end{array}$ & $\begin{array}{c}-0.077 \\
(-9.091)\end{array}$ & $\begin{array}{l}-0.076 \\
(-9.118)\end{array}$ & $\begin{array}{c}-0.028 \\
(-0.745)\end{array}$ & $\begin{array}{c}0.006 \\
(0.195)\end{array}$ \\
\hline Maturity & & $\begin{array}{c}0.019 \\
(7.720)\end{array}$ & $\begin{array}{c}0.019 \\
(7.681)\end{array}$ & $\begin{array}{c}0.019 \\
(7.720)\end{array}$ & $\begin{array}{c}-0.023 \\
(-1.812)\end{array}$ & $\begin{array}{c}0.030 \\
(3.067)\end{array}$ \\
\hline Log of 3 Year US. Treasury Rate & $\begin{array}{l}-0.056 \\
(-1.140)\end{array}$ & $\begin{array}{c}-0.177 \\
(-2.719)\end{array}$ & $\begin{array}{l}-0.152 \\
(-2.446)\end{array}$ & $\begin{array}{l}-0.097 \\
(-1.596)\end{array}$ & $\begin{array}{c}0.525 \\
(1.479)\end{array}$ & $\begin{array}{c}0.037 \\
(0.150)\end{array}$ \\
\hline $\begin{array}{l}\text { Log(10 Year-1 Year) } \\
\text { Treasury Rate }\end{array}$ & $\begin{array}{c}-0.140 \\
(-11.550)\end{array}$ & $\begin{array}{l}-0.020 \\
(-1.244)\end{array}$ & & & & \\
\hline Dummy for Private Borrower & $\begin{array}{c}0.323 \\
(24.210)\end{array}$ & $\begin{array}{c}0.140 \\
(4.118)\end{array}$ & $\begin{array}{c}0.141 \\
(4.156)\end{array}$ & $\begin{array}{c}0.229 \\
(8.851)\end{array}$ & $\begin{array}{c}0.223 \\
(1.945)\end{array}$ & $\begin{array}{c}0.352 \\
(4.272)\end{array}$ \\
\hline Dummy for Latin American loan & $\begin{array}{c}-0.389 \\
(-17.730)\end{array}$ & $\begin{array}{c}0.119 \\
(2.745)\end{array}$ & $\begin{array}{c}0.126 \\
(2.592)\end{array}$ & $\begin{array}{c}-0.033 \\
(-0.753)\end{array}$ & & \\
\hline Number of Borrowing & & $\begin{array}{l}-0.058 \\
(-7.822)\end{array}$ & $\begin{array}{l}-0.058 \\
(-7.722)\end{array}$ & $\begin{array}{l}-0.057 \\
(-7.702)\end{array}$ & $\begin{array}{l}-0.055 \\
(-3.709)\end{array}$ & $\begin{array}{l}-0.029 \\
(-6.089)\end{array}$ \\
\hline Credit Rating Residual & $\begin{array}{c}0.014 \\
(19.980)\end{array}$ & $\begin{array}{c}-0.024 \\
(-14.139)\end{array}$ & $\begin{array}{c}-0.024 \\
(-13.535)\end{array}$ & $\begin{array}{l}-0.021 \\
(-14.983)\end{array}$ & $\begin{array}{c}-0.017 \\
(-2.685)\end{array}$ & $\begin{array}{l}-0.039 \\
(-2.902)\end{array}$ \\
\hline Debt/GNP & $\begin{array}{c}-1.018 \\
(-25.810)\end{array}$ & $\begin{array}{c}0.921 \\
(9.119)\end{array}$ & $\begin{array}{c}0.915 \\
(9.069)\end{array}$ & $\begin{array}{c}0.569 \\
(6.974)\end{array}$ & $\begin{array}{c}0.854 \\
(2.673)\end{array}$ & \\
\hline Dummy for Debt Rescheduling & $\begin{array}{l}-0.099 \\
(-4.230)\end{array}$ & $\begin{array}{c}0.462 \\
(10.852)\end{array}$ & $\begin{array}{c}0.464 \\
(10.937)\end{array}$ & $\begin{array}{c}0.404 \\
(9.873)\end{array}$ & & \\
\hline Debt Service/Exports & $\begin{array}{c}0.934 \\
(15.290)\end{array}$ & $\begin{array}{c}0.515 \\
(4.305)\end{array}$ & $\begin{array}{c}0.515 \\
(4.322)\end{array}$ & $\begin{array}{c}0.587 \\
(5.796)\end{array}$ & $\begin{array}{c}0.399 \\
(1.779)\end{array}$ & $\begin{array}{l}2.461 \\
(2.758)\end{array}$ \\
\hline GDP Growth & & $\begin{array}{l}-12.930 \\
(-2.759)\end{array}$ & $\begin{array}{l}-13.016 \\
(-2.726)\end{array}$ & $\begin{array}{l}-11.275 \\
(-2.384)\end{array}$ & $\begin{array}{l}-10.432 \\
(-2.261)\end{array}$ & $\begin{array}{l}-30.433 \\
(-2.804)\end{array}$ \\
\hline $\begin{array}{l}\text { Standard Deviation of Export } \\
\text { growth }\end{array}$ & & $\begin{array}{c}0.380 \\
(3.942)\end{array}$ & $\begin{array}{c}0.363 \\
(3.805)\end{array}$ & $\begin{array}{c}0.346 \\
(3.639)\end{array}$ & $\begin{array}{c}1.147 \\
(1.326)\end{array}$ & $\begin{array}{l}1.879 \\
(2.789)\end{array}$ \\
\hline Reserves/Imports & $\begin{array}{c}0.042 \\
(5.720)\end{array}$ & & $\begin{array}{l}-0.002 \\
(-0.197)\end{array}$ & $\begin{array}{c}0.071 \\
(4.965)\end{array}$ & & \\
\hline Reserves/Short Term Debts & $\begin{array}{l}-0.005 \\
(-4.010)\end{array}$ & & & $\begin{array}{l}-0.067 \\
(-7.355)\end{array}$ & & \\
\hline $\begin{array}{l}\text { Ratio of Short Term Debt to Total } \\
\text { Debt }\end{array}$ & $\begin{array}{l}-0.296 \\
(-6.190)\end{array}$ & $\begin{array}{c}1.385 \\
(8.046)\end{array}$ & $\begin{array}{l}1.370 \\
(7.863)\end{array}$ & $\begin{array}{c}0.919 \\
(4.981)\end{array}$ & $\begin{array}{c}1.151 \\
(2.854)\end{array}$ & $\begin{array}{l}0.199 \\
(0.396)\end{array}$ \\
\hline Ratio of Domestic Credit to GDP & $\begin{array}{c}0.086 \\
(12.510)\end{array}$ & $\begin{array}{c}-0.432 \\
(-12.999)\end{array}$ & $\begin{array}{c}-0.428 \\
(-12.763)\end{array}$ & $\begin{array}{c}-0.404 \\
(-12.151)\end{array}$ & $\begin{array}{l}-0.342 \\
(-5.513)\end{array}$ & $\begin{array}{l}-0.263 \\
(-0.370)\end{array}$ \\
\hline $\begin{array}{l}\text { Ratio of Domestic Credit to GDP* } \\
\text { Ratio of Domestic Credit to GDP }\end{array}$ & & $\begin{array}{c}0.024 \\
(6.836)\end{array}$ & $\begin{array}{c}0.024 \\
(6.741)\end{array}$ & $\begin{array}{c}0.023 \\
(6.637)\end{array}$ & & \\
\hline $\begin{array}{l}\text { Number of Repeated } \\
\text { Borrowing }{ }^{\star} \text { Ratio of Short Term } \\
\text { Debt to Total Debt }\end{array}$ & & $\begin{array}{c}0.074 \\
(6.326)\end{array}$ & $\begin{array}{c}0.074 \\
(6.249)\end{array}$ & $\begin{array}{c}0.072 \\
(6.200)\end{array}$ & & \\
\hline $\begin{array}{l}\text { GDP Growth*Ratio of Short Term } \\
\text { Debt to Total Debt }\end{array}$ & & $\begin{array}{l}-51.986 \\
(-5.617)\end{array}$ & $\begin{array}{l}-51.739 \\
(-5.488)\end{array}$ & $\begin{array}{l}-53.567 \\
(-5.760)\end{array}$ & & \\
\hline $\begin{array}{l}\text { GDP Growth*Ratio of Domestic } \\
\text { Credit to GDP }\end{array}$ & & $\begin{array}{c}16.605 \\
(15.983)\end{array}$ & $\begin{array}{c}16.494 \\
(15.930)\end{array}$ & $\begin{array}{c}16.322 \\
(15.869)\end{array}$ & & \\
\hline Constant & & $\begin{array}{c}4.799 \\
(28.555)\end{array}$ & $\begin{array}{c}4.762 \\
(28.673)\end{array}$ & $\begin{array}{c}4.817 \\
(30.934)\end{array}$ & $\begin{array}{c}3.473 \\
(4.472)\end{array}$ & $\begin{array}{c}3.574 \\
(4.451)\end{array}$ \\
\hline Lambda & & $\begin{array}{l}-0.197 \\
(-2.899)\end{array}$ & $\begin{array}{c}-0.198 \\
(-2.896)\end{array}$ & $\begin{array}{c}0.025 \\
(0.632)\end{array}$ & $\begin{array}{c}0.087 \\
(0.740)\end{array}$ & $\begin{array}{c}0.289 \\
(5.521)\end{array}$ \\
\hline Number of observations/loans & 8055 & 4551 & 4545 & 4545 & 443 & 319 \\
\hline Log Likelihood & -3447.289 & -6947.429 & -6948.183 & -6923.735 & -989.023 & -365.182 \\
\hline
\end{tabular}

Note: all regressions include dummies for industrial sectors, currency of denomination and supranational as defined in table 6. 
Table 12: Correlation Matrix

\begin{tabular}{|c|c|c|c|c|c|c|c|c|c|c|}
\hline All & $\begin{array}{l}\text { Credit } \\
\text { Rating } \\
\text { Residual }\end{array}$ & Debt/GNP & $\begin{array}{l}\text { Dummy for } \\
\text { Debt } \\
\text { Rescheduling }\end{array}$ & $\begin{array}{l}\text { Debt Service } \\
\text { /Exports }\end{array}$ & $\begin{array}{l}\text { GDP } \\
\text { Growth }\end{array}$ & $\begin{array}{l}\text { Standard } \\
\text { Deviation } \\
\text { of Export } \\
\text { Growth } \\
\end{array}$ & $\begin{array}{l}\text { Ratio of } \\
\text { Short Term } \\
\text { Debt to } \\
\text { Total Debt }\end{array}$ & $\begin{array}{l}\text { Ratio of } \\
\text { Domestic } \\
\text { Credit } \\
\text { To GDP } \\
\end{array}$ & $\begin{array}{l}\text { Reserves } \\
\text { /Imports }\end{array}$ & $\begin{array}{l}\text { Reserves } \\
\text { /Short } \\
\text { Term } \\
\text { Debts } \\
\end{array}$ \\
\hline $\begin{array}{l}\text { Credit Rating } \\
\text { Residual } \\
\text { Debt/GNP }\end{array}$ & -0.01 & 1 & & & & & & & & \\
\hline $\begin{array}{l}\text { Dummy for Debt } \\
\text { Rescheduling }\end{array}$ & -0.02 & 0.24 & 1 & & & & & & & \\
\hline GDP Growth & 0.00 & -0.23 & -0.14 & -0.26 & 1 & & & & & \\
\hline $\begin{array}{l}\text { Standard Deviation } \\
\text { of Export Growth }\end{array}$ & 0.01 & 0.05 & -0.01 & -0.01 & -0.02 & 1 & & & & \\
\hline $\begin{array}{l}\text { Ratio of Short } \\
\text { Term Debt to } \\
\text { Total Debt }\end{array}$ & 0.19 & -0.27 & -0.16 & -0.38 & 0.14 & -0.20 & 1 & & & \\
\hline $\begin{array}{l}\text { Ratio of Domestic } \\
\text { Credit to GDP }\end{array}$ & 0.33 & -0.28 & -0.26 & -0.46 & 0.35 & -0.03 & 0.40 & 1 & & \\
\hline $\begin{array}{l}\text { Reserves } \\
\text { /Imports }\end{array}$ & -0.05 & -0.01 & -0.03 & 0.17 & 0.13 & 0.02 & -0.03 & 0.13 & 1 & \\
\hline $\begin{array}{l}\text { Reserves/ } \\
\text { Short Term Debts }\end{array}$ & -0.26 & -0.07 & -0.04 & -0.10 & -0.04 & 0.04 & 0.01 & -0.08 & 0.07 & 1 \\
\hline Latin America & $\begin{array}{l}\text { Credit } \\
\text { Rating } \\
\text { Residual }\end{array}$ & Debt/GNP & $\begin{array}{l}\text { Dummy for } \\
\text { Debt } \\
\text { Rescheduling }\end{array}$ & $\begin{array}{l}\text { Debt Service } \\
\text { /Exports }\end{array}$ & $\begin{array}{l}\text { GDP } \\
\text { Growth }\end{array}$ & $\begin{array}{l}\text { Standard } \\
\text { Deviation } \\
\text { of Export } \\
\text { Growth }\end{array}$ & $\begin{array}{l}\text { Ratio of } \\
\text { Short Term } \\
\text { Debt to } \\
\text { Total Debt }\end{array}$ & $\begin{array}{c}\begin{array}{l}\text { Ratio of } \\
\text { Domestic }\end{array} \\
\text { Credit } \\
\text { To GDP }\end{array}$ & $\begin{array}{l}\text { Reserves } \\
\text { /Imports }\end{array}$ & $\begin{array}{l}\text { Reserves } \\
\text { /Short } \\
\text { Term } \\
\text { Debts }\end{array}$ \\
\hline $\begin{array}{l}\text { Credit Rating } \\
\text { Residual } \\
\text { Debt/GNP }\end{array}$ & $\begin{array}{c}1 \\
0.18\end{array}$ & 1 & & & & & & & & \\
\hline $\begin{array}{l}\text { Dummy for Debt } \\
\text { Rescheduling }\end{array}$ & 0.06 & 0.12 & 1 & & & & & & & \\
\hline $\begin{array}{l}\text { Debt Service } \\
\text { /Exports }\end{array}$ & 0.24 & 0.08 & 0.03 & 1 & & & & & & \\
\hline $\begin{array}{l}\text { Ratio of Short } \\
\text { Term Debt to } \\
\text { Total Debt }\end{array}$ & -0.30 & -0.14 & -0.01 & -0.27 & -0.01 & 0.16 & 1 & & & \\
\hline $\begin{array}{l}\text { Ratio of Domestic } \\
\text { Credit to GDP }\end{array}$ & 0.32 & 0.70 & -0.09 & 0.06 & -0.03 & 0.01 & -0.04 & 1 & & \\
\hline $\begin{array}{l}\text { Reserves } \\
\text { /Imports }\end{array}$ & 0.04 & -0.16 & -0.07 & 0.10 & 0.12 & -0.19 & -0.25 & -0.05 & 1 & \\
\hline $\begin{array}{l}\text { Reserves/ } \\
\text { Short Term Debts }\end{array}$ & -0.40 & -0.22 & -0.01 & -0.33 & 0.13 & 0.18 & -0.07 & -0.20 & 0.24 & 1 \\
\hline South Asia & $\begin{array}{l}\text { Credit } \\
\text { Rating } \\
\text { Residual }\end{array}$ & Debt/GNP & $\begin{array}{l}\text { Debt Service } \\
\text { /Exports }\end{array}$ & GDP Growth & $\begin{array}{l}\text { Standard } \\
\text { Deviation of } \\
\text { Export } \\
\text { Growth } \\
\end{array}$ & $\begin{array}{l}\text { Ratio of } \\
\text { Short Term } \\
\text { Debt to } \\
\text { Total Debt } \\
\end{array}$ & $\begin{array}{l}\text { Ratio of } \\
\text { Domestic } \\
\text { Credit } \\
\text { to GDP } \\
\end{array}$ & $\begin{array}{l}\text { Reserves } \\
\text { /Imports }\end{array}$ & $\begin{array}{l}\text { Reserves } \\
\text { /Short } \\
\text { Term } \\
\text { Debts } \\
\end{array}$ & \\
\hline $\begin{array}{l}\text { Credit Rating } \\
\text { Residual } \\
\text { Debt/GNP }\end{array}$ & $\begin{array}{c}1 \\
-0.37\end{array}$ & 1 & & & & & & & & \\
\hline $\begin{array}{l}\text { Debt } \\
\text { Service/Exports } \\
\text { GDP Growth }\end{array}$ & 0.05 & $\begin{array}{l}-0.60 \\
-0.42\end{array}$ & $\begin{array}{c}1 \\
-0.01\end{array}$ & 1 & & & & & & \\
\hline $\begin{array}{l}\text { Standard Deviation } \\
\text { of Export Growth } \\
\text { Ratio of Short Term }\end{array}$ & 0.13 & 0.53 & -0.26 & -0.16 & 1 & & & & & \\
\hline $\begin{array}{l}\text { Debt } \\
\text { to Total Debt } \\
\text { Ratio of Domestic }\end{array}$ & -0.70 & 0.65 & -0.52 & -0.24 & 0.34 & 1 & & & & \\
\hline $\begin{array}{l}\text { Credit } \\
\text { to GDP }\end{array}$ & 0.68 & -0.52 & 0.53 & 0.16 & -0.16 & -0.59 & 1 & & & \\
\hline Reserves/Imports & 0.18 & -0.45 & -0.11 & 0.59 & -0.33 & -0.35 & 0.05 & 1 & & \\
\hline $\begin{array}{l}\text { Reserves/ } \\
\text { Short Term Debts }\end{array}$ & -0.62 & 0.25 & -0.68 & 0.00 & -0.10 & 0.46 & -0.62 & 0.29 & 1 & \\
\hline
\end{tabular}




\section{APPENDIX A: Data sources and construction of variables}

\section{Loan characteristics}

The loan data set, obtained from Capital Data Loanware and further processed by the Emerging Markets Division of the International Monetary Fund, covers the period 1991 to 1997 and includes: (a) average weighted margins plus fees (in basis points, where one basis point is one-hundredth of a percentage point) (b) the amount of the issue (millions of US\$); (c) the maturity in years; (d) whether the borrower was a sovereign, other public sector entity, or private debtor; (e) number of borrowings by an entity during the period under consideration; (f) currency of issue; (g) borrower's industrial sector: manufacturing, financial services, utility or infrastructure, other services, or government (where government, in this case, refers to subsovereign entities and central banks, which could not be classified in the other four industrial sectors); (h) the country and regional identity of the borrower.

\section{Country characteristics}

\begin{tabular}{|c|c|c|c|c|}
\hline Variable & (billions) & Periodicity & Source & Series \\
\hline $\begin{array}{l}\text { Total external } \\
\text { debt (EDT) }\end{array}$ & US\$ & annual & WEO & $\mathrm{D}$ \\
\hline $\begin{array}{l}\text { Gross national } \\
\text { product (GNP, } \\
\text { current prices) }\end{array}$ & US\$ & annual & WEO & NGDPD \\
\hline $\begin{array}{l}\text { Gross domestic } \\
\text { product } \\
\text { (GDPNC, } \\
\text { current prices) }\end{array}$ & National & annual & WEO & NGDP \\
\hline $\begin{array}{l}\text { Gross domestic } \\
\text { product } \\
\text { (GDP90, } 1990 \\
\text { prices) }\end{array}$ & National & annual & WEO & NGDP_R \\
\hline $\begin{array}{l}\text { Total debt } \\
\text { service (TDS) }\end{array}$ & US\$ & annual & WEO & $\mathrm{DS}$ \\
\hline Exports (XGS) & US\$ & annual & WEO & $\mathrm{BX}$ \\
\hline Exports (X) & US\$ & monthly & IFS & $\mathrm{M \# c|70 \_ dzf}$ \\
\hline $\begin{array}{l}\text { Reserves } \\
(\text { RESIMF) }\end{array}$ & US\$ & quarterly & IFS & $\mathrm{q \# c| \_ 11 \_ dzf}$ \\
\hline Imports (IMP) & US\$ & quarterly & IFS & $\mathrm{q \# c|71 \_ dzf}$ \\
\hline
\end{tabular}




\begin{tabular}{|l|l|l|l|l|}
\hline Variable & (billions) & Periodicity & Source & Series \\
\hline $\begin{array}{l}\text { Domestic bank } \\
\text { credit } \\
(\text { CLM_PVT })^{23}\end{array}$ & National & quarterly & IFS & q\#c|32d_zf \\
\hline $\begin{array}{l}\text { Short-term bank } \\
\text { debt } \\
(\text { BISSHT })^{24}\end{array}$ & US\$ & semi-annual & BIS & \\
\hline $\begin{array}{l}\text { Total bank debt } \\
(\text { BISTOT })^{25}\end{array}$ & US\$ & semi-annual & BIS & \\
\hline $\begin{array}{l}\text { Credit rating } \\
(\text { CRTG })\end{array}$ & Scale & semi-annual & $\begin{array}{l}\text { Institutional } \\
\text { Investor }\end{array}$ & \\
\hline $\begin{array}{l}\text { Debt } \\
\text { rescheduling } \\
(\text { DRES })^{26}\end{array}$ & Indicator & annual & WDT/GDF & \\
\hline
\end{tabular}

\section{CONSTRUCTED VARIABLES:}

Debt/GNP

Debt service/Exports

GDP Growth

Standard deviation of

export growth

Reserves/Imports

Reserves/Short-term debt

Ratio of short-term debt

to total debt

Ratio of Domestic Credit

to GDP

\section{SOURCES:}

International Monetary Fund's World Economic Outlook (WEO) and International

Financial Statistics (IFS).

World Bank's World Debt Tables (WDT) and Global Development Finance (GDF).

Bank of International Settlements' The Maturity, Sectoral and Nationality Distribution

\footnotetext{
${ }^{23}$ Credit to private sector.

${ }^{24}$ Cross-border bank claims in all currencies and local claims in non-local currencies of maturity up to and including one year.

${ }^{25}$ Total consolidated cross-border claims in all currencies and local claims in non-local currencies.
} 
of International Bank Lending.

Credit ratings were obtained from Institutional Investor's Country Credit Ratings. Missing data for some countries was completed using the US State Department's Annual Country reports on Economic Policy and Trade Practices (which are available on the internet from http:www.state.gov/www/issues/economic/trade_reports/).

\section{U.S. interest rates}

http://www.bog.frb.fed.us/releases/H15/data/b/tcm3y.txt

Countries that issued loans: Algeria, Angola, Argentina, Bangladesh, Bahrain, Barbados, Bolivia, Brazil, Bulgaria, Chile, China, Colombia, Croatia, Cyprus, Czech Republic, Czechoslovakia, Dominican Republic, Ecuador, Egypt, El Salvador, Estonia, Ghana, Hong Kong, Hungary, India, Israel, Indonesia, Iran, Jamaica, Kazakstan, Kenya, South Korea, Kuwait, Laos, Latvia, Lebanon, Lesotho, Liberia, Lithuania, Malaysia, Mauritius, Macedonia, Mexico, Moldova, Morocco, Oman, Pakistan, Panama, Papua New Guinea, Peru, Philippines, Poland, Qatar, Romania, Russia, Saudi Arabia, Senegal, Seychelles, Singapore, Slovenia, South Africa, Sri Lanka, Taiwan, Thailand, Trinidad \& Tobago, Tunisia, Turkey, Ukraine, United Arab Emirates, Uruguay, Vietnam, Venezuela, Zambia, Zimbabwe. Other countries included in the analysis, but which were not recorded as having issued loans are: Costa Rica, Ethiopia, Guatemala, Nigeria, Paraguay and Slovak Republic.

\footnotetext{
${ }^{26}$ Indicator variable, which is equal to 1 if a debt rescheduling took place in the previous year and zero otherwise.
} 


\section{Appendix B: Determinants of bond issuance and spreads}

\begin{tabular}{|c|c|c|c|c|c|c|}
\hline \multicolumn{7}{|c|}{$\begin{array}{l}\text { Appendix table 1: Determinants of the probability of a bond issue } \\
\text { (t-statistics in parentheses) }\end{array}$} \\
\hline & \multicolumn{3}{|c|}{ Fixed Rate } & \multicolumn{3}{|c|}{ Floating Rate } \\
\hline & All & Latin America & East Asia & All & Latin America & East Asia \\
\hline Log of U.S. treasury rate & $\begin{array}{l}-0.725 \\
(-7.28)\end{array}$ & $\begin{array}{l}-0.740 \\
(-5.41)\end{array}$ & $\begin{array}{l}-1.337 \\
(-6.94)\end{array}$ & $\begin{array}{l}-0.172 \\
(-3.37)\end{array}$ & $\begin{array}{l}-0.079 \\
(-1.90)\end{array}$ & $\begin{array}{l}-0.661 \\
(-3.19)\end{array}$ \\
\hline Credit rating residual & $\begin{array}{r}0.013 \\
(13.46)\end{array}$ & $\begin{array}{l}0.013 \\
(6.30)\end{array}$ & $\begin{array}{l}0.001 \\
(0.32)\end{array}$ & $\begin{array}{r}0.009 \\
(16.28)\end{array}$ & $\begin{array}{l}0.003 \\
(4.87)\end{array}$ & $\begin{array}{l}0.014 \\
(3.89)\end{array}$ \\
\hline Debt/ gnp & $\begin{array}{l}-0.382 \\
(-5.35)\end{array}$ & $\begin{array}{r}-1.417 \\
(-15.19)\end{array}$ & $\begin{array}{l}0.023 \\
(0.12)\end{array}$ & $\begin{array}{l}-0.189 \\
(-4.88)\end{array}$ & $\begin{array}{l}-0.061 \\
(-3.29)\end{array}$ & $\begin{array}{l}-0.560 \\
(-2.95)\end{array}$ \\
\hline $\begin{array}{l}\text { Dummy for debt } \\
\text { rescheduling }\end{array}$ & $\begin{array}{l}-0.206 \\
(-5.09)\end{array}$ & $\begin{array}{l}0.024 \\
(0.70)\end{array}$ & $\begin{array}{l}-0.216 \\
(-2.67)\end{array}$ & $\begin{array}{l}-0.090 \\
(-4.42)\end{array}$ & $\begin{array}{l}0.001 \\
(0.07)\end{array}$ & \\
\hline Debt service/ exports & $\begin{array}{r}-0.541 \\
(5.03)\end{array}$ & $\begin{array}{r}1.792 \\
(18.83)\end{array}$ & $\begin{array}{l}-1.589 \\
(-3.55)\end{array}$ & $\begin{array}{l}-0.038 \\
(-0.62)\end{array}$ & $\begin{array}{l}0.173 \\
(8.53)\end{array}$ & $\begin{array}{l}0.611 \\
(1.46)\end{array}$ \\
\hline Reserves/gnp & $\begin{array}{l}-0.109 \\
(-5.02)\end{array}$ & $\begin{array}{l}-0.074 \\
(-0.86)\end{array}$ & $\begin{array}{r}-0.543 \\
(-10.36)\end{array}$ & $\begin{array}{l}-0.034 \\
(-3.59)\end{array}$ & $\begin{array}{l}-0.065 \\
(-2.60)\end{array}$ & $\begin{array}{l}-0.240 \\
(-5.69)\end{array}$ \\
\hline Private issuer & $\begin{array}{l}-0.033 \\
(-1.42)\end{array}$ & $\begin{array}{r}0.321 \\
(10.66)\end{array}$ & $\begin{array}{r}0.241 \\
(5.22)\end{array}$ & $\begin{array}{r}0.166 \\
(12.86)\end{array}$ & $\begin{array}{l}0.075 \\
(5.77)\end{array}$ & $\begin{array}{r}0.536 \\
(13.46)\end{array}$ \\
\hline Latin America & $\begin{array}{l}-0.212 \\
(-0.73)\end{array}$ & & & $\begin{array}{l}-0.120 \\
(-0.70)\end{array}$ & & \\
\hline \multicolumn{7}{|c|}{$\underline{\text { Latin American interactions }}$} \\
\hline Log of U.S. treasury rate & $\begin{array}{l}0.086 \\
(0.56)\end{array}$ & & & $\begin{array}{l}-0.009 \\
(-0.08)\end{array}$ & & \\
\hline Credit rating residual & $\begin{array}{l}-0.002 \\
(-1.05)\end{array}$ & & & $\begin{array}{l}0.003 \\
(1.82)\end{array}$ & & \\
\hline Debt/gnp & $\begin{array}{l}-0.841 \\
(-7.81)\end{array}$ & & & $\begin{array}{l}0.048 \\
(0.84)\end{array}$ & & \\
\hline Dummy for debt & 0.295 & & & 0.246 & & \\
\hline Debt service/ exports & $\begin{array}{l}1.006 \\
(7.43)\end{array}$ & & & $\begin{array}{l}0.432 \\
(5.62)\end{array}$ & & \\
\hline Reserves/gnp & $\begin{array}{l}0.045 \\
(0.58)\end{array}$ & & & $\begin{array}{l}-0.114 \\
(-1.97)\end{array}$ & & \\
\hline Private issuer & $\begin{array}{l}0.348 \\
(8.92)\end{array}$ & & & $\begin{array}{l}-0.016 \\
(-0.73)\end{array}$ & & \\
\hline Number of observations & 3904 & 1762 & 717 & 3140 & 1042 & 789 \\
\hline Pseudo R-Squared & 0.3498 & 0.4687 & 0.2695 & 0.3826 & 0.3165 & 0.3481 \\
\hline
\end{tabular}

Source: Eichengreen and Mody (1998b). 


\section{Appendix table 2: Determinants of spreads with selectivity correction (t-statistics in parentheses)}

\begin{tabular}{|c|c|c|c|c|c|}
\hline & \multicolumn{3}{|c|}{ Fixed Rate } & \multicolumn{2}{|c|}{ Floating Rate } \\
\hline & All & $\begin{array}{r}\text { Latin } \\
\text { America }\end{array}$ & East Asia & All & East Asia \\
\hline Log amount & $\begin{array}{l}0.030 \\
(1.00)\end{array}$ & $\begin{array}{l}-0.018 \\
(-0.72)\end{array}$ & $\begin{array}{l}0.067 \\
(0.83)\end{array}$ & $\begin{array}{l}-0.128 \\
(-3.55)\end{array}$ & $\begin{array}{l}-0.185 \\
(-4.96)\end{array}$ \\
\hline Maturity & $\begin{array}{l}0.011 \\
(1.96)\end{array}$ & $\begin{array}{l}0.000 \\
(0.06)\end{array}$ & $\begin{array}{l}0.020 \\
(1.52)\end{array}$ & $\begin{array}{l}0.025 \\
(2.14)\end{array}$ & $\begin{array}{l}0.030 \\
(2.71)\end{array}$ \\
\hline Private placement & $\begin{array}{r}0.110 \\
(2.320\end{array}$ & $\begin{array}{l}0.089 \\
(2.41)\end{array}$ & $\begin{array}{l}0.009 \\
(0.06)\end{array}$ & $\begin{array}{l}-0.089 \\
(-1.28)\end{array}$ & $\begin{array}{l}-0.033 \\
(-0.45)\end{array}$ \\
\hline Log of U.S. treasury rate & $\begin{array}{l}-0.249 \\
(-1.19)\end{array}$ & $\begin{array}{l}0.330 \\
(1.68)\end{array}$ & $\begin{array}{l}-1.048 \\
(-1.55)\end{array}$ & $\begin{array}{l}-0.090 \\
(-0.31)\end{array}$ & $\begin{array}{l}0.375 \\
(1.23)\end{array}$ \\
\hline Credit rating residual & $\begin{array}{r}-0.038 \\
(-13.22)\end{array}$ & $\begin{array}{l}-0.034 \\
(-8.55)\end{array}$ & $\begin{array}{l}-0.021 \\
(-2.13)\end{array}$ & $\begin{array}{l}-0.034 \\
(-5.65)\end{array}$ & $\begin{array}{r}-0.058 \\
(-10.82)\end{array}$ \\
\hline Debt/gnp & $\begin{array}{l}0.535 \\
(2.71)\end{array}$ & $\begin{array}{l}1.548 \\
(7.05)\end{array}$ & $\begin{array}{l}-1.126 \\
(-1.68)\end{array}$ & $\begin{array}{l}0.024 \\
(0.12)\end{array}$ & $\begin{array}{l}0.596 \\
(1.89)\end{array}$ \\
\hline Dummy for debt rescheduling & $\begin{array}{l}0.305 \\
(5.12)\end{array}$ & $\begin{array}{l}0.085 \\
(1.62)\end{array}$ & $\begin{array}{l}0.136 \\
(0.38)\end{array}$ & $\begin{array}{l}0.547 \\
(3.70)\end{array}$ & \\
\hline Debt service/ exports & $\begin{array}{l}1.488 \\
(6.70)\end{array}$ & $\begin{array}{l}-0.308 \\
(-1.43)\end{array}$ & $\begin{array}{l}5.809 \\
(4.45)\end{array}$ & $\begin{array}{l}1.410 \\
(5.12)\end{array}$ & $\begin{array}{l}1.934 \\
(3.42)\end{array}$ \\
\hline Gdp growth & $\begin{array}{l}-9.541 \\
(-3.21)\end{array}$ & $\begin{array}{l}0.447 \\
(0.17)\end{array}$ & $\begin{array}{l}-1.292 \\
(-0.08)\end{array}$ & $\begin{array}{r}-13.646 \\
(-3.12)\end{array}$ & $\begin{array}{r}-36.093 \\
(-4.70)\end{array}$ \\
\hline Variance of export growth & $\begin{array}{l}1.525 \\
(4.74)\end{array}$ & $\begin{array}{l}1.557 \\
(4.26)\end{array}$ & $\begin{array}{l}1.372 \\
(1.91)\end{array}$ & $\begin{array}{l}0.384 \\
(1.20)\end{array}$ & $\begin{array}{l}0.920 \\
(3.02)\end{array}$ \\
\hline Private issuer & $\begin{array}{l}0.353 \\
(6.19)\end{array}$ & $\begin{array}{l}-0.029 \\
(-0.57)\end{array}$ & $\begin{array}{l}0.689 \\
(4.51)\end{array}$ & $\begin{array}{l}0.436 \\
(4.73)\end{array}$ & $\begin{array}{l}0.119 \\
(1.24)\end{array}$ \\
\hline Latin America & $\begin{array}{l}0.326 \\
(4.28)\end{array}$ & & & $\begin{array}{r}0.090 \\
(0.066)\end{array}$ & \\
\hline Israel & $\begin{array}{r}-2.299 \\
(-12.78)\end{array}$ & & & & \\
\hline Yen issue & $\begin{array}{l}-0.159 \\
(-2.20)\end{array}$ & $\begin{array}{l}-0.010 \\
(-0.13)\end{array}$ & $\begin{array}{l}-0.361 \\
(-2.33)\end{array}$ & $\begin{array}{l}-0.323 \\
(-2.26)\end{array}$ & $\begin{array}{l}-0.344 \\
(-2.95)\end{array}$ \\
\hline Deutche Mark issue & $\begin{array}{l}-0.127 \\
(-1.52)\end{array}$ & $\begin{array}{l}0.106 \\
(1.54)\end{array}$ & $\begin{array}{l}-2.130 \\
(-6.22)\end{array}$ & $\begin{array}{l}-0.209 \\
(-1.02)\end{array}$ & $\begin{array}{l}-0.538 \\
(-1.51)\end{array}$ \\
\hline Supranational & $\begin{array}{l}-0.668 \\
(-2.34)\end{array}$ & $\begin{array}{l}-0.604 \\
(-4.24)\end{array}$ & & & \\
\hline Lambda & $\begin{array}{l}0.062 \\
(1.00)\end{array}$ & $\begin{array}{r}-0.550 \\
(-19.52)\end{array}$ & $\begin{array}{l}0.306 \\
(1.54)\end{array}$ & $\begin{array}{l}0.138 \\
(1.46)\end{array}$ & $\begin{array}{l}-0.466 \\
(-6.05)\end{array}$ \\
\hline Constant & $\begin{array}{r}4.49 \\
(10.61)\end{array}$ & $\begin{array}{r}5.068 \\
(11.77)\end{array}$ & $\begin{array}{l}5.181 \\
(3.91)\end{array}$ & $\begin{array}{l}4.844 \\
(8.69)\end{array}$ & $\begin{array}{l}5.221 \\
(9.07)\end{array}$ \\
\hline Number of bonds & 1025 & 663 & 233 & 525 & 415 \\
\hline Log of likelihood & -2679.062 & -1165.464 & -682.423 & -1350.864 & -687.122 \\
\hline
\end{tabular}

Source: Eichengreen and Mody (1998b). 


\section{References}

Allen, T.J. (1990), "Developments in the International Syndicated Loan Market in the 1980s," Bank of England Quarterly Bulletin 30, pp. 71-77.

Cantor, Richard and Frank Packer (1996), “The Credit Rating Industry," Federal Reserve Bank of New York Quarterly Review (Summer/Fall), pp. 1-26.

Eaton, Jonathan and Mark Gersovitz (1981), "Poor-Country Borrowing in Private Financial Markets and the Repudiation Issue," Princeton Studies in International Finance No. 47, International Finance Section, Department of Economics, Princeton University.

Edwards, Sebastian (1986), "The Pricing of Bonds and Bank Loans in International Markets: An Empirical Analysis of Developing Countries’ Foreign Borrowing," European Economic Review 30, pp. 565-589.

Eichengreen, Barry and Ashoka Mody (1998a), "What Explains Changing Spreads on Emerging-Market Debt? Fundamentals or Market Sentiment?" NBER Working Paper no. 6408 (February).

Eichengreen, Barry and Ashoka Mody (1998b), "Interest Rates in the North and Capital Flows to the South: Is There a Missing Link?” International Finance 1, pp.35-58.

Feldstein, Martin (1999) “A Self-Help Guide for Emerging Market Economies,” Foreign Affairs 78 (March/April, 1999).

Fischer, Stanley (1999), "On the Need for an International Lender of Last Resort," American Economic Association and American Finance Association Meetings, January 3, 1999, http://www.imf.org/external/np/speeches/1999/010399.HTM.

Folkerts-Landau, David (1985), "The Changing Role of International Bank Lending in Development Finance," Staff Papers 32, pp. 317-363.

Gutentag, Jack and Richard Herring (1985), The Current Crisis in International Lending, Washington, D.C.: The Brookings Institution.

Haque, Nadeem, Mammohan Kumar, Nelson Mark and Donald Mathieson (1996), "The Economic Content of Indicators of Developing Country Creditworthiness," Staff Papers 43, pp. 688-724.

International Monetary Fund (1998), International Capital Markets: Developments, Prospects, and Key Policy Issues, Washington D.C.

James, Christopher (1990), "Heterogeneous Creditors and the Market Value of Bank LDC Loan Portfolios,” Journal of Monetary Economics 25, pp. 325-346.

Kletzer, Kenneth (1994), "Asymmetries of Information and LDC Borrowing with Sovereign Risk," Economic Journal 94, pp. 287-307. 
Levine, Ross and Sara Zervos (1998), "Stock Markets, Banks, and Economic Growth," American Economic Review 88, pp. 537-558.

Preece, Dianna and Donald J. Mullineaux (1996), "Monitoring, Loan Renegotiability, and Firm Value: The Role of Lending Syndicates," Journal of Banking and Finance 20, pp.577-593.

Sachs, Jeffrey and Daniel Cohen (1982), "LDC Borrowing with Default Risk," NBER Working Paper no. 925 (July). 